\title{
Stratigraphy of the
}

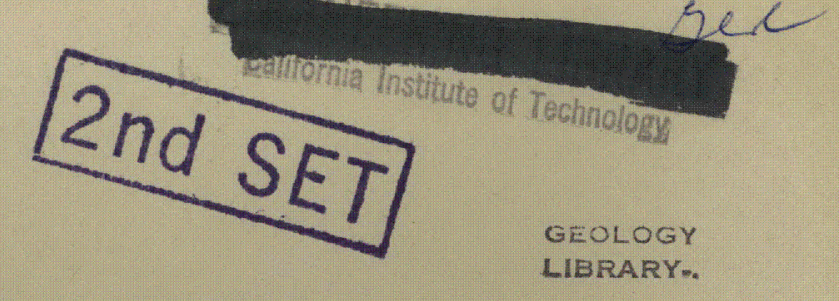

Pierre Shale, Valley City and

Pembina Mountain Areas

\section{North Dakota}

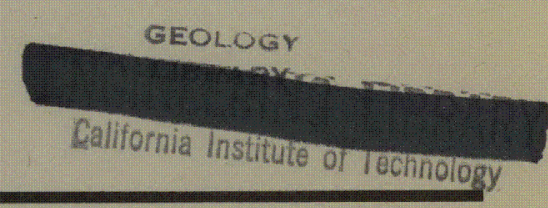

GEOLOGICAL SURVEY PROFESSIONAL PAPER 392-A

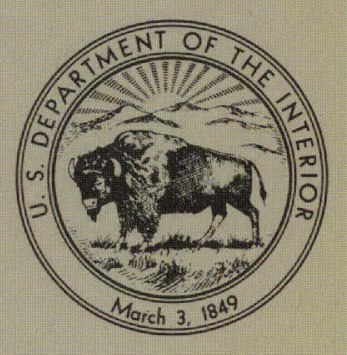

CALIFORNIA

INSTITUTE OF

JUL 141965

TECHNOLOGY 


\section{Stratigraphy of the}

\section{Pierre Shale, Valley City and}

\section{Pembina Mountain Areas}

\section{North Dakota}

By JAMES R. GILL and WILLIAM A. COBBAN

STUDIES OF THE PIERRE SHALE IN THE NORTHERN GREAT PLAINS

GEOLOGICAL SURVEY PROFESSIONAL PAPER 392-A

Five lithologic subdivisions of the Pierre Shale in eastern North Dakota correlated with equivalent rocks in central South Dakota, eastern Wyoming, central Montana, and southern Manitoba

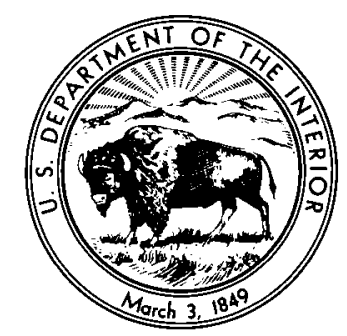




\section{UNITED STATES DEPARTMENT OF THE INTERIOR}

\section{STEWART L. UDALL, Secretary}

\section{GEOLOGIGAL SURVEY}

Thomas B. Nolan, Director

For sale by the Superintendent of Documents, U.S. Government Printing Office Washington, D.C. 20402 - Price 25 cents (paper cover) 


\section{CONTENTS}

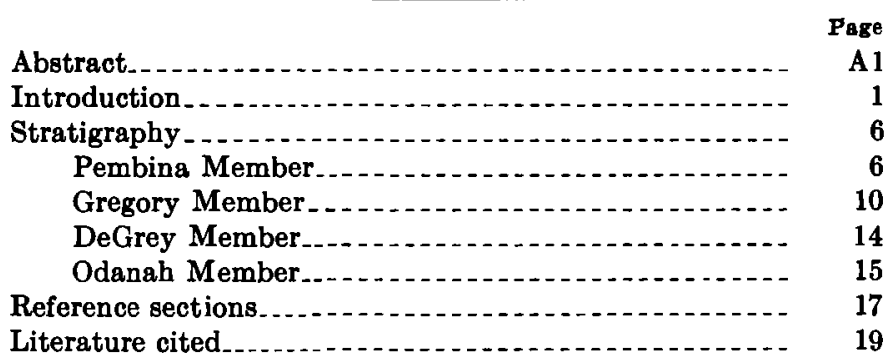

ILLUSTRATIONS

Figure 1. Index map showing localities discussed in text

Maps showing location of reference sections and

and fossil collections, Valley City and Pembina Mountain areas.....

3. Ammonite sequence and correlation chart for Campanian and lower Maestrichtian rocks ....................

4. Correlation chart of lower part of Pierre Shale in eastern North Dakota and central South Dakota..........

5. Photograph of interbedded bentonite and organic-rich shale in lower part of Pembina Member.............

6. Correlation chart of groups of bentonite in lower part of Pembina Member.

7. Photograph of Pierre Shale exposed in roadcut east side of Sheyenne River 



\title{
STRATIGRAPHY OF THE PIERRE SHALE, VALLEY GITY AND PEMBINA MOUNTAIN AREAS, NORTH DAKOTA
}

\author{
By James R. Gill and William A. Cobban
}

\begin{abstract}
Reconnaissance examination of widely scattered outcrops of Upper Cretaceous rocks in the hearily glaciated areas of eastern North Dakota provides the basis for the first formal subdivision of the Pierre Shale in these areas. Five distinct units are present which can be related by both lithology and fossil content to equivalent units in the type Pierre Shale of central South Dakota and to units in the Vermilion River and Riding Mountain Formations of Manitoba. Existing stratigraphic names in current usage in Manitoba and central South Dakota are applied to four of the five members of the Pierre recognized in North Dakota. The Manitoba name Pembina is applied to the basal member of the Pierre, and the South Dakota names Gregory Member and DeGrey Member have been assigned to the two succeeding younger members. The Manitoba name Odanah is assigned to the hard siliceous shale that overlies the DeGrey Member. The fifth and youngest member of the Pierre Shale exposed in eastern North Dakota remains unnamed because of a lack of adequate stratigraphic and faunal data.
\end{abstract}

\section{INTRODUCTION}

Much of the Pierre Shale of Late Cretaceous age is exposed in two main areas in North Dakota (fig. 1) : (1) the Valley City area in the central southeastern part of the State and (2) the Pembina Mountain area along the international boundary in the northeastern part of the State. The two areas are about 150 miles apart. Glacial deposits cover the Pierre Shale in the eastern part of the State except for isolated exposures of a few feet or a few tens of feet of strata in some of the deeper valleys. Although known for many years, the outcrops of the Pierre in North Dakota yielded few fossils, and the relations of these strata to the type section of the Pierre Shale along the Missouri River in South Dakota were not determined.

As part of the stratigraphic studies involved in the geochemical investigations of the Pierre Shale and its stratigraphic equivalents (Tourtelot, 1962; Tourtelot, Schultz, and Gill, 1960; Gill and Cobban, 1961, 1962), we made a reconnaissance study of the Valley City and Pembina Mountain areas because these exposures include the northeasternmost strata of the Pierre Shale available for study. They thus are important in studying the paleogeography of the eastern part of the Pierre basin of deposition. In addition, the outcrops in North Dakota provide an important datum point for better understanding of the Pierre equivalents to the north in Manitoba and Saskatchewan.

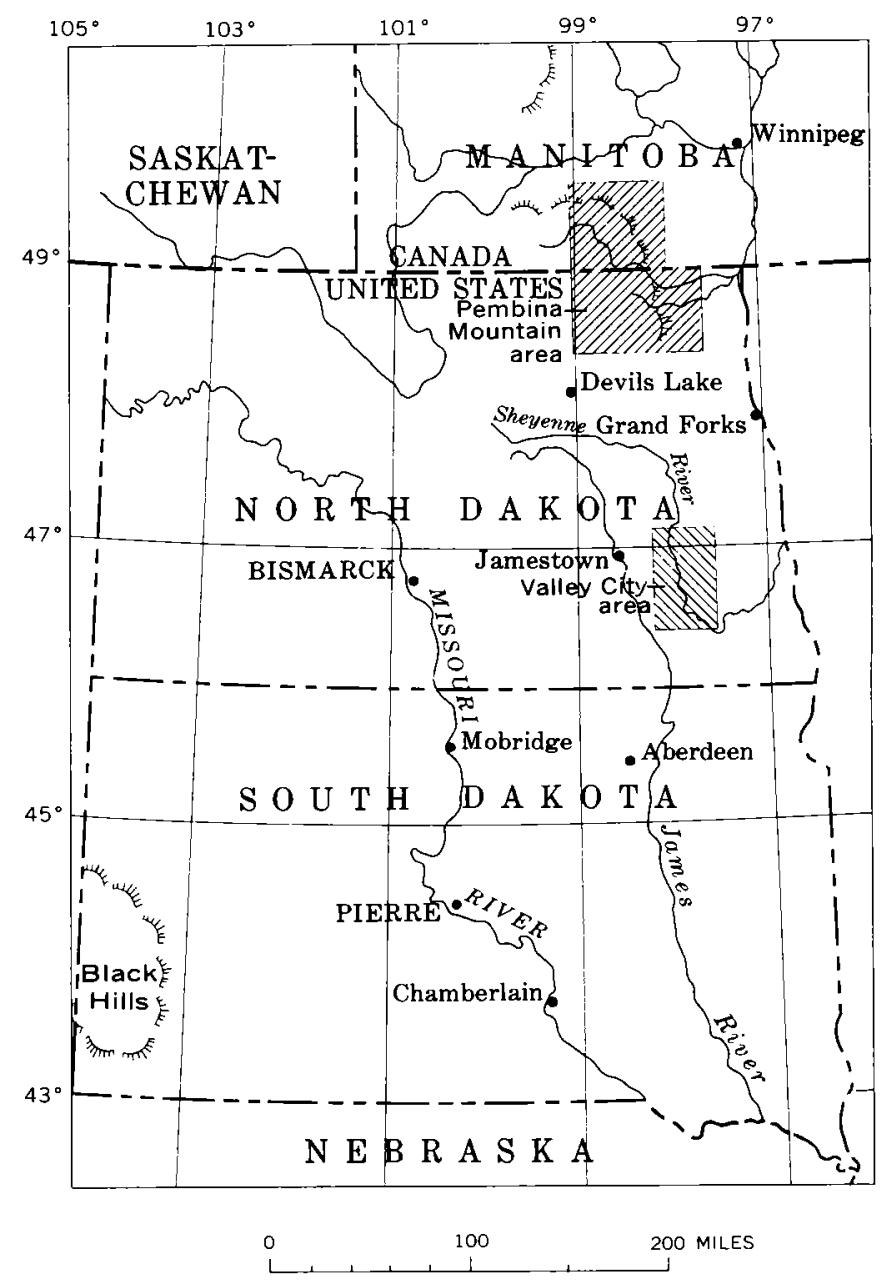

Figdre 1.-Localities discussed in tert. 
In the Valley City area (fig. $2 A$ ), the Sheyenne River has cut through the thin veneer of glacial deposits that mantle the upland surface and has formed a valley 150 to 175 feet deep and about a mile wide. Moderately good exposures of the Pierre Shale and the underlying Niobrara Formation are present in the bluffs of the river and its major tributaries. These exposures extend from Valley City southward for a distance of about 25 miles to the vicinity of Fort Ransom. A few miles east of Fort Ransom 100 feet or more of pale-yellowishorange-weathering marlstone beds of the Niobrara For- mation is exposed in roadcuts along the Sheyenne River. The lower 175 feet of the Pierre Shale and the upper few feet of the Niobrara Formation are exposed in roadcuts near Little Yellowstone Park (fig. $2 A$, loc. 5). These outcrops consist of about 50 feet of hard dark shale overlain by about 120 feet of pale-yellow-weathering calcareous shale and marlstone. North of this locality, in the vicinity of Kathryn, there are good exposures of the basal dark shale and the overlying calcareous beds. Between Kathryn and Valley City, dark-gray to black bentonitic shales containing abundant black manganif-

\section{EXPLANATION}

(1)

Type locality of Pembina Member of Vermilion River Formation Section after Wickenden (1945)

(2)

Pembina River section

(3a) (3b)

Tongue River section

(4)

North Valley City section

(5)

Little Yellowstone Park section $\times$

Fossil localities

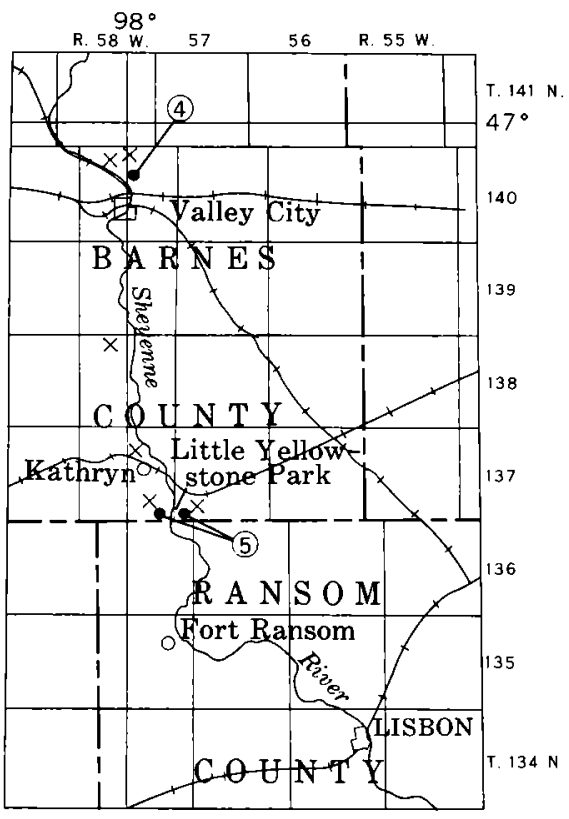

A. VALLEY CITY AREA, NORTH DAKOTA

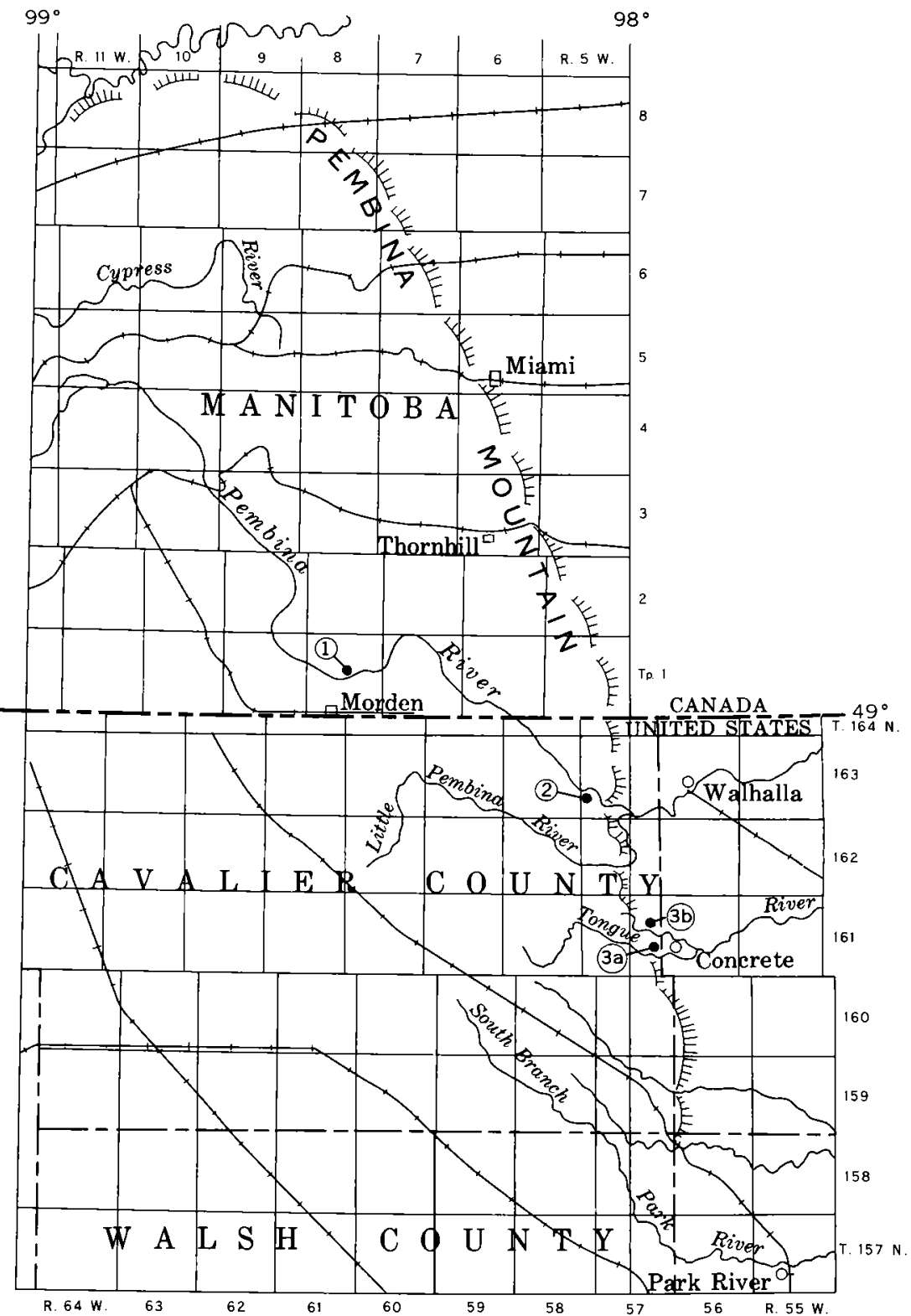

B. PEMBINA MOUNTAIN AREA, MANITOBA AND NORTH DAKOTA 30 MILES

Figure 2.--Location of reference sections and fossll collections, Valley City and Pembina Mountain areas. 
erous concretions overlie the calcareous beds and crop out high on the valley walls of the Sheyenne River. These dark shales slump extensively but form a striking dark band that is generally bare of vegetation and that contrasts sharply with the underlying light-colored calcareous beds.

The Pembina Mountain area as defined in this report follows the usage of Upham (1895). It includes the 200 - to 300 -foot-high east-facing escarpment that extends from near the town of Park River (fig. $2 B$ ) in northeastern North Dakota north-northwestward about 100 miles to near the town of Treherne in southern Manitoba. This imposing topographic feature, though not a mountain in the strict sense, has been referred to as Pembina Mountain or second mountain since the establishment of the first settlement in the region. D. D. Owen visited the area in 1848 during the course of his geological survey of Wisconsin, Iowa, and Minnesota, and remarked that Pembina Mountain was really a terrace or tableland which originally formed the ancient shore of a great body of water, glacial Lake Agassiz (Owen, 1852, p. 178). Pembina Mountain has also been referred to at various times as the Pembina Escarpment (Dawson, 1881, p. 15A), Manitoba Escarpment (Tyrrell, 1890), Second Pembina Mountain and Pembina Mountain (Upham, 1895, p. 41), Pembina Mountains (Leonard, 1904, p. 147), and Pembina Hills (Laird, 1951).

The upper surface of Pembina Mountain is a relatively smooth gently westward sloping surface cut on nearly horizontal beds of hard siliceous shale in the upper part of the Pierre, which are in turn covered by a thin layer of glacial drift. The steep eastern face of Pembina Mountain is heavily wooded, and bedrock exposures are poor except along the major streams and rivers that breach the mountain front. Good exposures are to be found along the North, Middle, and South Branches of the Park River, the Tongue River, and the Little Pembina and Pembina Rivers. $\mathbf{A}$ part of the Niobrara Formation and 100 feet or more of Pierre Shale can be seen along many of these drainages. The Pierre Shale of this area consists of a basal unit about 80 feet thick of moderately hard dark organic-rich shale containing numerous beds of bentonite. These beds are overlain by about 50 feet of lighter colored calcareous and bentonitic shale that slumps extensively. The calcareous shale is capped by from 65 feet to more than 100 feet of light-gray hard siliceous shale which forms the bedrock surface of much of the Pembina Mountain area.

Cpham (1895), in his monograph on the glacial Lake Agassiz, is the first geologist known to us to record the Pierre Shale in eastern North Dakota. The most extensive investigations of the Pierre were conducted by the State Geological Survey of North Dakota in the early 1900's. These studies were concerned largely with the economic potential of the clays and marls of the Pierre for the manufacture of brick and cement, although some attempt was made to correlate units within the Pierre. Results of these investigations were published by Leonard (1904, 1906), Babcock and Clapp (1906), Barry and Melsted (1908), and Kline (1942). A very cursory examination of the Pierre along the Sheyenne River apparently was made by Willard (1909) during his mapping of the glacial deposits of the Jamestown and Tower quadrangles.

The stratigraphic succession of lithologic units within the Pierre Shale in eastern North Dakota and in South Dakota remained largely unknown for many years. It was not until 1937 that the type Pierre of central South Dakota was described in detail and the stratigraphic framework for the formation was established by Searight (1937). The first and apparently only attempt to relate the Pierre Shale of North Dakota to the type sequence in South Dakota was by Kline (1942, p. 355), who suggested that calcareous beds cropping out at Valley City, N. Dak., might be equivalent to chalk beds in the upper part of the Gregory Member of Searight (1937) of the Pierre Shale in South Dakota. Leonard (1904, p. 152-153) originally assigned these calcareous beds in North Dakota to the Pierre, but later (1906, p. 69 ) he assigned them to the Niobrara Formation as did most subsequent workers.

Our correlation of the Pierre Shale of eastern North Dakota (figs. 3, 4) is based on an examination of outcrops in the Valley City and Pembina Mountain areas. Detailed sections were measured and fossil collections were made in each of these areas. In addition, many of the readily accessible scattered outcrops between the two areas were visited. Our observations have been supplemented by unpublished stratigraphic data obtained by H. A. Tourtelot of the U.S. Geological Survey in a previous reconnaissance of the Pierre Shale in eastern North Dakota. Dr. Wilson M. Laird, State Geologist of North Dakota, Dr. F. D. Holland, Jr., Mr. Rodney Feldmann, and Mr. A. M. Cvancara, of the Department of Geology, University of North Dakota, contributed generously of their knowledge of the geology of the region and reviewed the final manuscript. Data concerning the Pierre equivalents in the adjacent part of Manitoba were obtained in the course of a brief reconnaissance we made in the summer of 1963 . Stratigraphic data for the Pierre Shale along the Missouri River in central South Dakota are based on our observations, on unpublished material supplied by Tourtelot and $\mathrm{L}$. G. Schultz of the U.S. Geological Survey, and on the published record. 


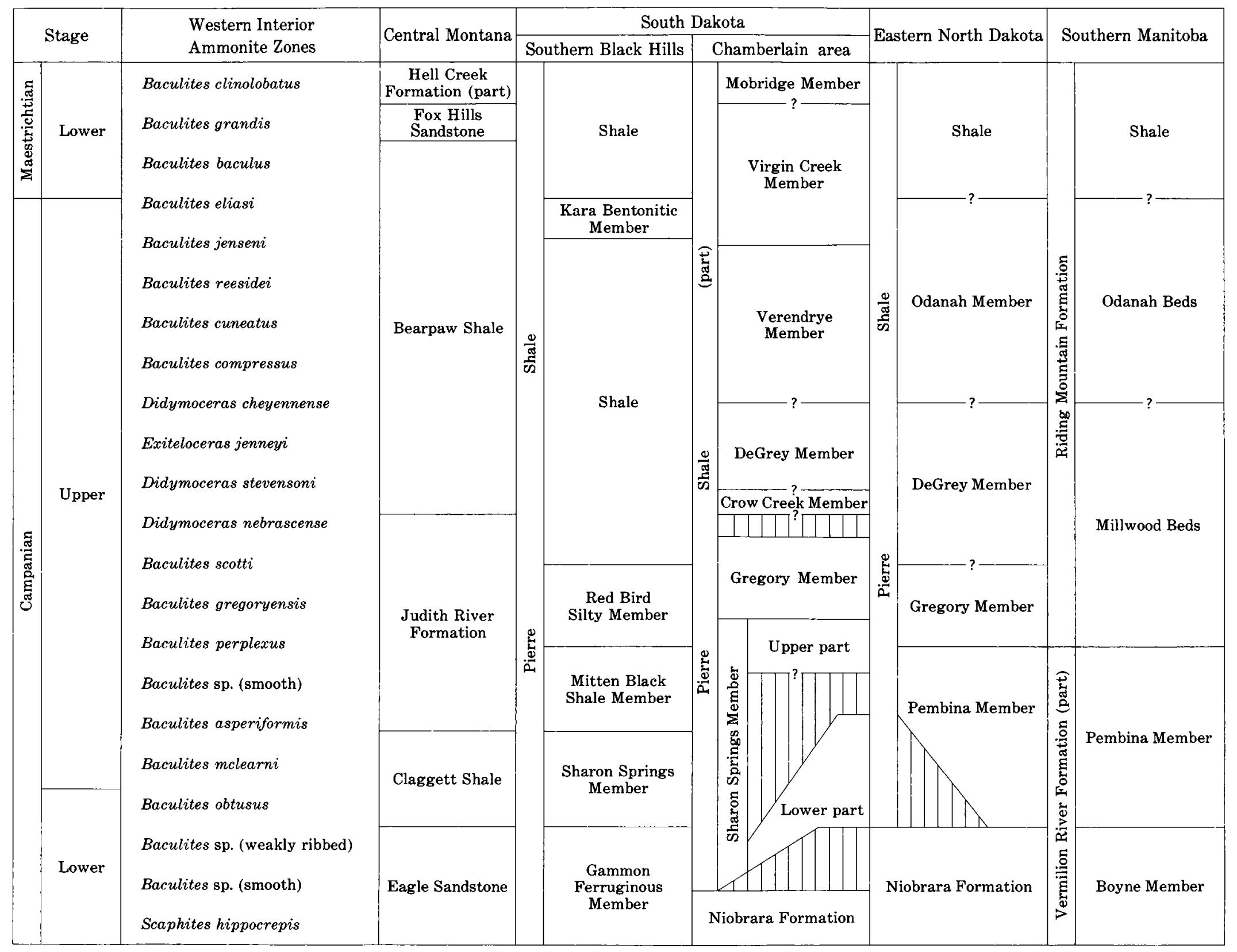

Fiodral 3.-Ammonite sequence for Campanian and lower Maestrichtian rocks in the western Interior of the United States and comparison of stratigraphic nomenclature of central Montana, North and South Dakota, and southern Manitoba. 


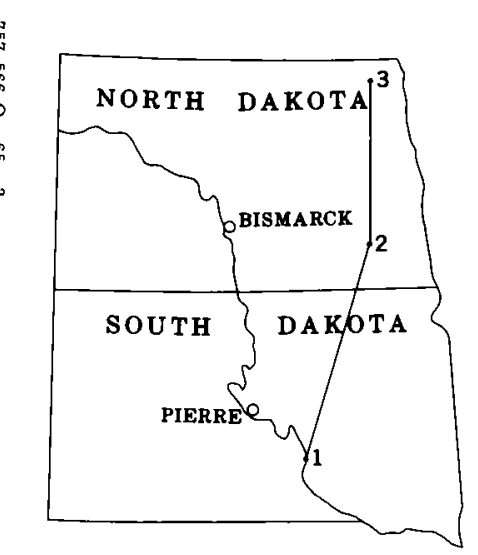

3

Pembina Mountain

Tongue River area

Sheyenne River

Little Yellowstone Park area

Missouri River

Wolf Creek-Chamberlain a rea

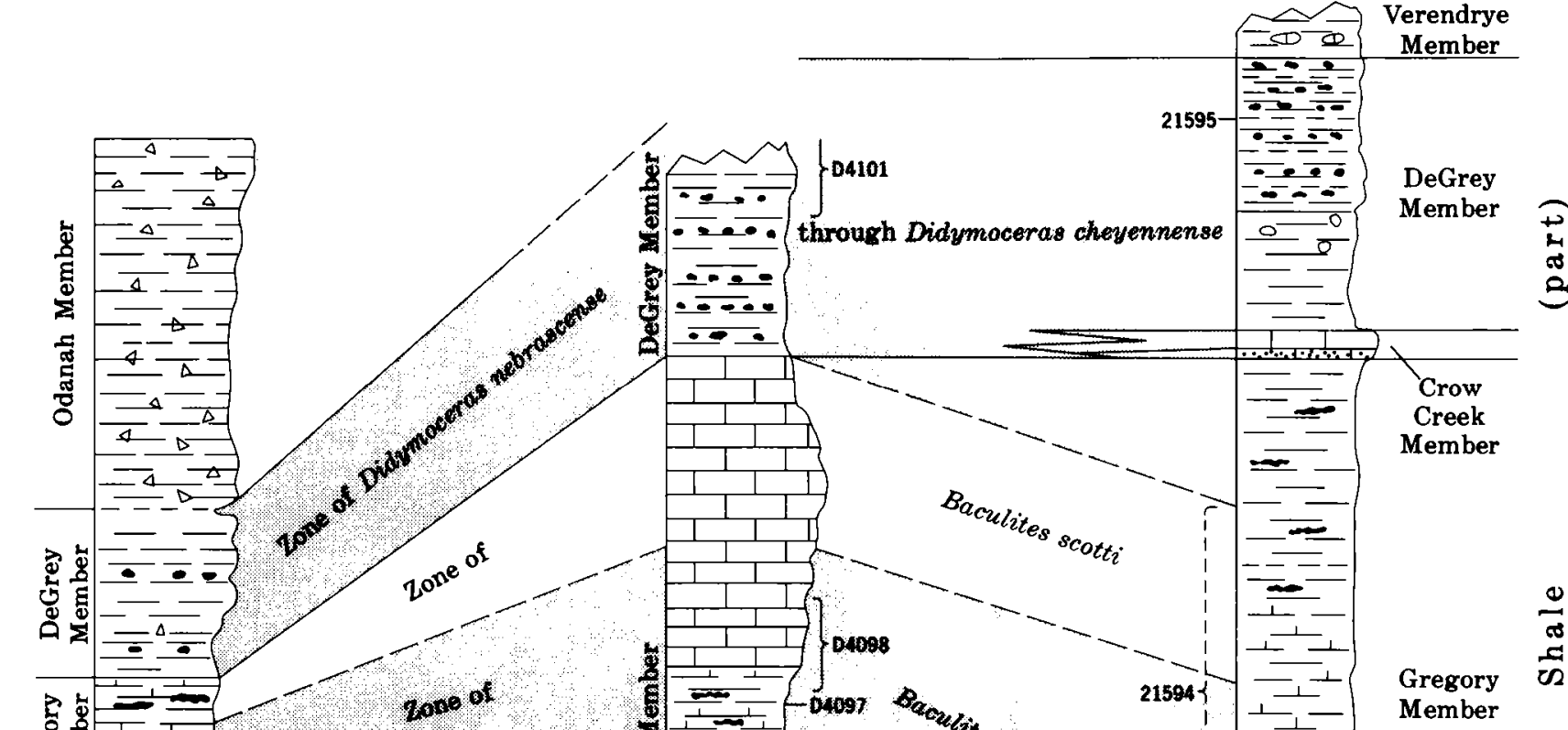

Nonbentonitic shale

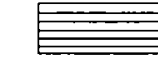

Organic-rich shale I -

Calcareous shale

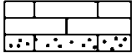

Sandy marlstone and chalk

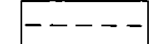

Bentonite bed

Concretions

Phosphate Ironistone

Limestone Manganese

D4095

$$
5 \text { fossil localit }
$$
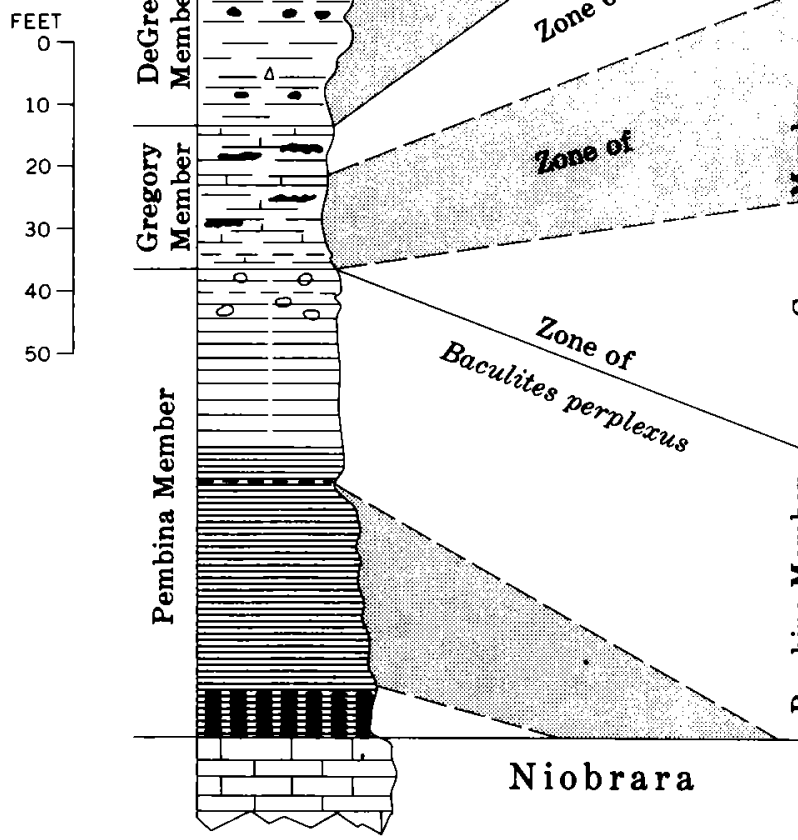

140 MILES

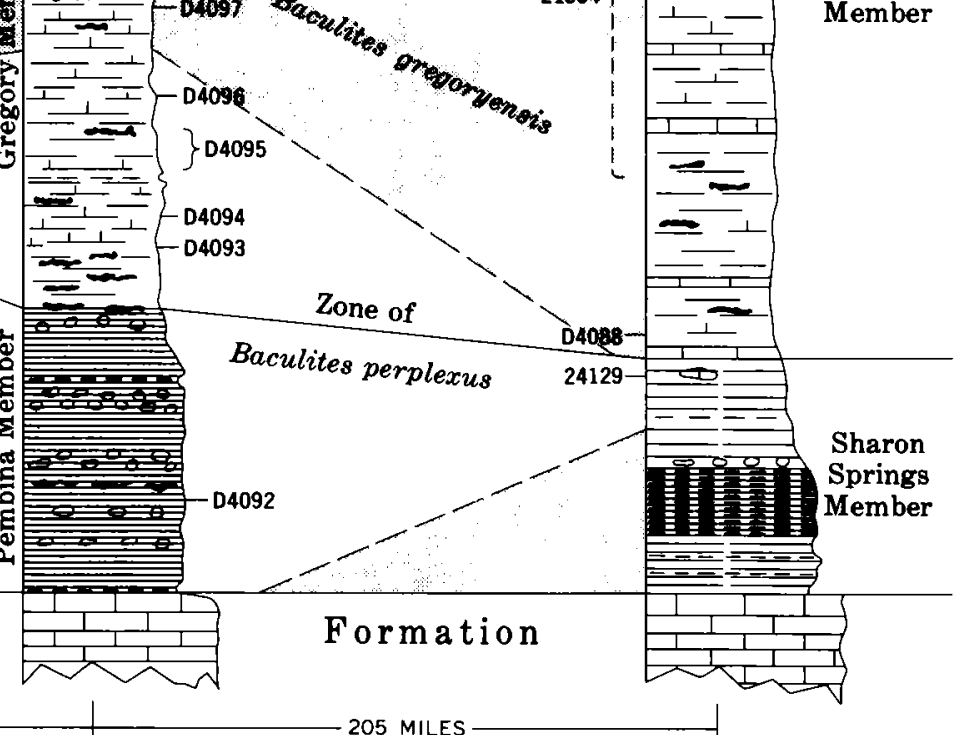

Figdra 4.- Correlation of the lower part of the Plerre Shale in eastern North Dakota and central South Dakota, showing Inferred stratigraphic range of ammonite zones (alternating stlppled and blank areas) and position of fossil collections. Missourl River section is a composite of unpublished sections measured by H. A. Tourtelot and L. G. Schultz. 
The Pierre Shale outcrops in eastern North Dakota which we examined are divisible into four major lithologic units. They are, from oldest to youngest, (1) dark-gray to brownish-black shale that contains numerous thin beds of bentonite in the lower part, (2) lightweathering calcareous shale and marlstone, (3) bentonitic shale and claystone that contains abundant manganiferous ironstone concretions, and (4) light-gray hard siliceous shale. In addition, a fifth unit of soft dark shale, not seen by us, was described by Barry and Melsted (1908, p. 180) as overlying the light-gray hard siliceous shale. This last unit appears to have been largely eroded from eastern North Dakota. We believe that new names are not necessary for any of the lower four units; the Manitoba names Pembina and Odanah can be applied to the oldest and the youngest, whereas the South Dakota names Gregory and DeGrey fit the remaining units. Figure 4 shows the probable position of ammonite zones in these lower four units and the correlation of these units with the type Pierre Shale of central South Dakota.

\section{STRATIGRAPHY \\ PEMBINA MEMBER}

The Pembina Member, the lowest unit of the Pierre Shale in the Pembina Mountain area, was originally defined by Kirk (1930, p. 130B) as the Pembina Beds and was treated by him as the uppermost of three members of the Vermilion River Formation. The member was named for exposures on Pembina Mountain and along the Pembina River valley in southern Manitoba. Pembina Mountain lies partly in North Dakota and partly in Manitoba, and the Pembina River cuts through the mountain in both areas (Upham, 1895, pl.9). Kirk described the member as consisting of no more than 80 feet of dark noncalcareous shale resting on the lighter colored speckled calcareous Boyne Member of the Vermilion River Formation (Niobrara Formation of North Dakota). Along Pembina River, 4 miles north of the North Dakota boundary, Kirk noted that the lower 11 feet of the Pembina Member contained at least 6 beds of bentonitic clay and formed a very striking unit known as the black and white beds. The remainder and greater part of the member he described as black and chocolatebrown shale, of which the latter was very fissile and contained abundant macerated fish remains. Later, Wickenden (1945, p. 43-44) visited the same locality and presented a more detailed surface section as well as a bore-hole section. According to Wickenden the total thickness of the nember is a little more than 80 feet. In the lower 18 feet, he measured 18 layers of cream-colored bentonite, each 0.8 foot or less thick, whereas in the rest of the member he recorded only 9 very thin layers of bentonite. More recently Tovell (1948, p. 4, diagram 47-7B) mentioned the twofold division of the Pembina Member and included many graphic sections of the member along the Pembina River. The main bentonite-bearing part of the Pembina Member is pictured on figure 5 ; it has also been presented by Wickenden (1945, pl. 4, fig. b) and by Davies and others (1962, pl. 19, fig. A).

The strata making up the Pembina Member continue southward into North Dakota along Pembina Mountain, where they form the lowest member of the Pierre Shale. We know of no reason why the name Pembina cannot be applied to these strata in North Dakota, especially as the type locality is on the same escarpment. Accordingly, the name Pembina Member of the Pierre Shale is

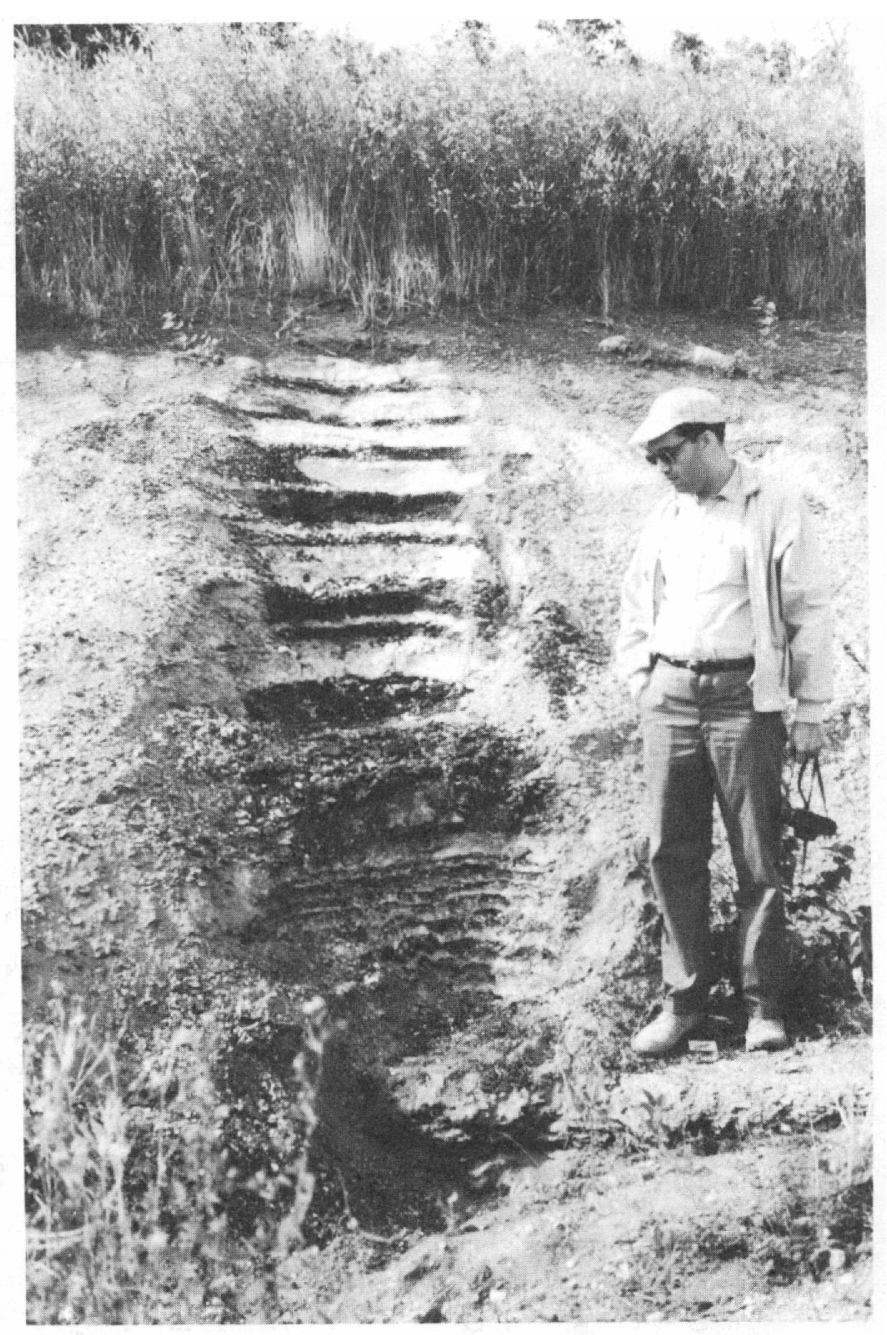

FIGORE 5.-Interbedded bentonite (light bands) and organic-rich shale (dark bands) in the lower part of the Pembina Member of the Plerre Shale exposed in roadcut near the Pemblna Rtver in the $\mathrm{SW} 1 / 4$ sec. 30 , T. 163 N., R. 57 W., Cavaller County, N. Dak. (See Pemblna Rlver section.) Man is standing at the contact between the Pierre and Niobrara; thin beds of shale and bentonite just above the Nlobrara may be equivalent to the Gammon Ferruginous Member of the Plerre Shale. 
given to these rocks in eastern North Dakota. The rocks of the Pembina Member are lithologically similar to the Sharon Springs Member of the Pierre Shale along the Missouri River in central South Dakota and extension of that name into North Dakota has been considered by us. We believe that the usage of the name Pembina, which has its type locality a few miles north of the international boundary, is preferable to extending the name Sharon Springs 700 miles from its type locality in western Kansas (Elias, 1931, p. 58-77).

The rocks herein assigned to the Pembina Member in the Pembina Mountain area were first described by Leonard (1904, p. 148), who presented a generalized stratigraphic section along the Tongue River, which is the next major drainage south of the Pembina River. Leonard noted that gray calcareous shale, assigned to the Niobrara Formation, was separated from bluishgray clay shale, assigned to the Pierre Shale, by a black carbonaceous shale unit which he apparently believed to be part of the Pierre, although he did not definitely state so. This black shale unit was described in two parts - a lower 6- to 8-foot unit of "black, carbonaceous clay shale layers alternating with white clay seams," (see fig. 5) and an upper 60-foot unit of "black and highly carbonaceous shale *** cut by joints and irregular cracks which are filled with gypsum" and containing "occasional thin layers of white clay toward the base." In a subsequent paper Leonard (1906, p. 68-71) definitely assigned these beds to the Pierre Shale and observed that the "black and white bands" persisted over a great area. The "white bands" were described later by Barry and Melsted (1908, p. 172) as "yellow layers." These layers were also termed "fullers earth" by Kline (1942, p. 354), who gave a section through the lower part of the Pierre Shale near the Tongue River. Her section can be summarized as a lower part of 13 feet of black shale, alternating with more than 17 thin layers of "fullers earth," and an upper part of 58 feet of black shale that has "fullers earth partings" in the lower 8 feet and abundant selenite crystals in the overlying part. Kline believed the "fullers earth" beds to be local in distribution, although Leonard (1906, p. 71) and Barry and Melsted (1908, p. 172) had earlier pointed out their wide distribution and Leonard $(1919$, p. 10$)$ even drew attention to a 2 -inch bed that could be traced for 25 miles. More recently Laird (1951, p. 12) suggested that these "fullers earth" clays were probably bentonite that came from volcanoes several hundred miles away.

Regional stratigraphic studies of the Pierre Shale and equivalent rocks farther west in the Dakotas and adjacent States indicate that the bentonite beds in the lower part of the Pembina Member and equivalent units (Sharon Springs Member of the Pierre Shale, and the
Claggett Shale) are the result of an extended period of explosive volcanism that took place some 700 miles west of Pembina Mountain, in the general area of the Elkhorn Mountains of western Montana. We believe that these bentonites may be equivalent to a part or all of the 2,500 feet of welded tuff and ash-fall crystal tuff that make up the middle member of the Elkhorn Mountains Volcanics (Klepper, Weeks, and Ruppel, 1957, p. 32) in the area between Helena and Three Forks, Mont. These bentonites may also be the lateral equivalents of ash-flow and welded tuffs that make up a part of the western facies of the Two Medicine Formation (Schmidt, 1963) in the area of Wolf Creek, Mont.

The apparent purity of the bentonite and the uniform thickness and lateral persistence of individual beds suggest that each bed may represent one or more ash falls. The continuity of groups of bentonite beds in the Pembina Mountain area of Manitoba and North Dakota is shown in figure 6. These bentonite beds are distinctive features in time-equivalent rocks throughout much of the Dakotas, Montana, Wyoming, Nebraska, Colorado, and the adjacent Provinces in Canada. The beds thus far examined are dominantly calcium bentonite (nonswelling). They range from a fraction of an inch to several feet in thickness, the thicker beds being more common in the western areas closer to the source of the ash. These bentonites have been mined for many years in the Miami-Thornhill area in southern Manitoba.

The Pembina bentonites are unusually absorbent and are used extensively in Canada in the bleaching of petroleum and fatty oils (Gallay, 1938, p. 9; Bannatyne, 1963, p. 9-18). Equivalent bentonites in the Dakotas probably have the same desirable physical and chemical properties, but at the present time they are not being exploited. A small quantity of bentonite has been mined from the basal bed (Ardmore Bentonite Bed of Spivey, 1940) of the Sharon Springs Member of the Pierre Shale in the vicinity of Buffalo Gap and Ardmore in the southern Black Hills (Connolly and O'Harra, 1929, p. 326 ; Spivey, 1940, p. 1).

We examined the Pembina Member in the valleys of the Pembina and Tongue Rivers in the Pembina Mountain area. A composite section in the Tongue River area revealed about 75 feet as the total thickness of the member; an 80-foot thickness was determined by Wickenden $(1945$, p. 43-44) at a locality in southern Manitoba about 21 miles north of Tongue River.

The lower or bentonite-rich part of the member is well exposed along the main road in the Pembina River valley about 7 miles west of Walhalla in the $S W 1 / 4$ sec. 30, T. 163 N., R. 57 W. (see Pembina River section; also figs. 5,6$)$, and near the old cement plant on the Olson Farm on the Tongue River in the NE $1 / 4$ sec. 25, T. 161 N., R. $57 \mathrm{~W}$. In the Pembina River valley, where the 
SW1/4 sec. 27, Tp. 1, R. 8 W.

Principal meridian

Manitoba

NE1/4 sec. 25, T. $161 \mathrm{~N}$.

North Dakota

by H. A. Tourtelot

EXPLANATION

wry

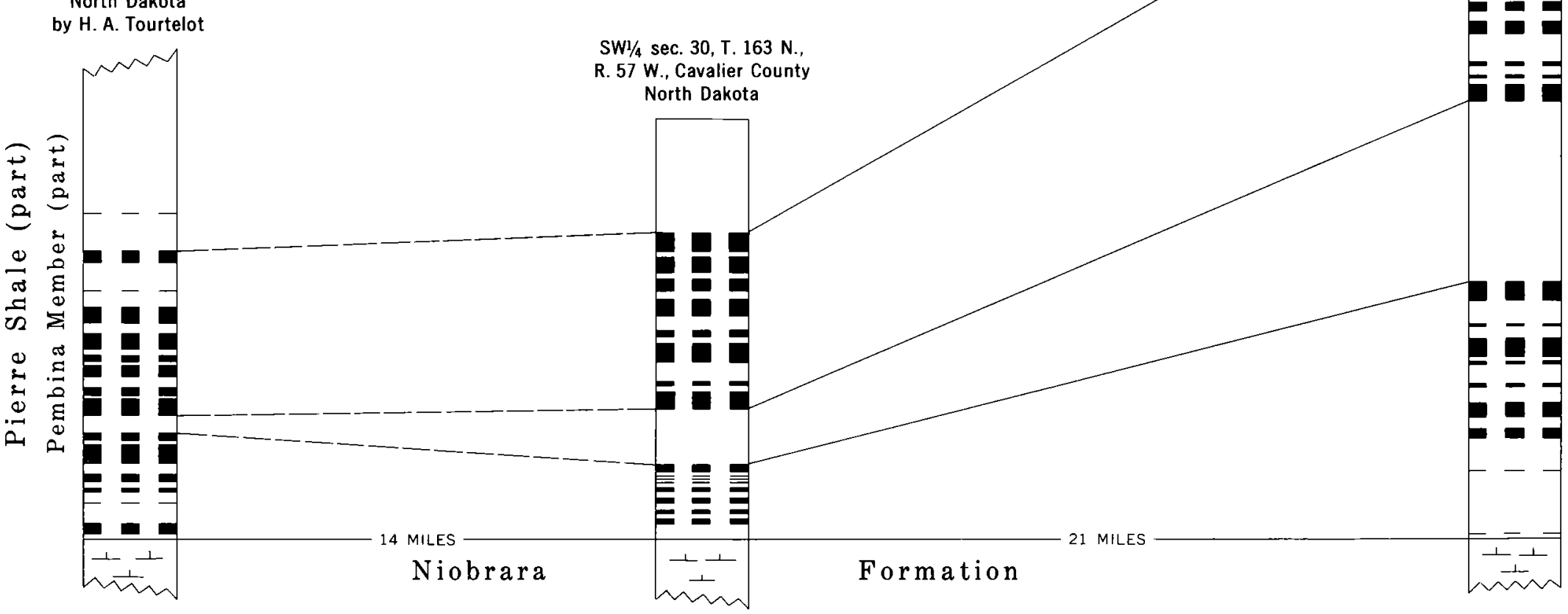

Figdre 6.-Correlation of groups of bentonite beds in the lower part of the Pembina Member of the Pierre Shale in eastern North Dakota with those in the Pemblna Member of the Vermilion River Formation in southern Manitoba. Manitoba section from Wickenden (1945). 
bentonite-rich part of the member is nearly 10 feet thick, a threefold division is apparent. The lower 2 feet contains eight very thin layers of bentonite of which only the uppermost is as much as 3 inches thick. This sequence of beds may be a partial time equivalent of the Gammon Ferruginous Member of the Pierre Shale. This basal group of thin bentonites is separated from an upper and thicker group of bentonites by 1.5 feet of shale devoid of bentonite. The upper group of bentonite beds is about 5 feet thick and contains eight or more layers of bentonite many of which are 5 or 6 inches thick and none of which are separated by more than 8 inches of shale. The threefold division of the bentonite-rich part of the Pembina Member apparently thickens northward into Manitoba, as indicated by the section on the Pembina River measured by Wickenden (1945, p. 43-44). The lower part of Wickenden's section can be summarized, from bottom to top, as follows : (1) A 6.5-foot unit of shale containing 9 layers of bentonite, (2) a 4.9-foot unit of shale that lacks bentonite, and (3) a 7.4-foot unit of shale containing 10 layers of bentonite none of which is separated by more than 1.7 feet of shale (fig. 6 ).

The upper or main part of the Pembina Member is well exposed in the vicinity of the Tongue River retention dam T-3-5 in the NE $1 / 4$ sec. 24, T. 161 N., R. 57 W. (See Pembina Mountain section, units 29-31.) There it is 67 feet thick and consists chiefly of dark-gray to brownish-black shale that contains only a few thin layers of bentonite. Yellowish seams of jarosite and colorless plates of selenite are common. Small brown fishbones and fish scales are abundant. Gypsum-encrusted phosphate nodules are present in the upper 15 feet. Gypsiferous limonitic baculites are present sparingly, but none is sufficiently well preserved for determination to species. Barry and Melsted (1908, p. 184) measured the lower 35 feet at a locality about 8 miles farther south, where they described the material-herein referred to as jarosite-as forming bright-yellow hard crusts that resembled sulfur but tested like earthy limonite.

In the Sheyenne River area only the upper part of the Pembina Member is present, and it is exposed about 20 miles south of Valley City. The upper part of the Pembina Member rests directly on the Niobrara Formation, as outcrops show in the new cut on the north side of North Dakota Highway 46 on the east side of Sheyenne River valley. (See Little Yellowstone Park section, units 5-12.) Here the Pembina Member is 44 feet thick and consists chiefly of grayish-brown to brownish-black shale that contains gypsum-encrusted phosphate nodules in the upper half and yellowishorange jarosite seams throughout much of the member. A few ironstone concretions are present in the interval 14-17 feet above the base. Bentonite is represented by two thin closely spaced layers at the base and by two beds in the upper half of the member. A few poorly preserved gypsiferous limonitic baculites are present in the lower 13 feet, and one well-preserved specimen of Baculites perplexus Cobban was found in a small ironstone concretion 14 feet above the base.

The member correlates with the Claggett Shale of central Montana, with the Sharon Springs and Mitten Black Shale Members of the Pierre Shale of the southern part of the Black Hills of South Dakota and eastern Wyoming, and with the Sharon Springs Member of the Pierre Shale in the Missouri River valley of south-central South Dakota (fig. 3).

The Claggett Shale of Montana is a dark-gray to dark-brownish-gray shale that contains a conspicuous group of closely spaced beds of bentonite in the lower part and a few thin layers in the higher part. It can be readily correlated with the Pembina Member by its lithologic character but timewise it correlates with perhaps only the lower half of the Pembina Member. The Claggett Shale, in its type area at the mouth of the Judith River in central Montana, contains Baculites obtusus Meek in the bentonite-rich basal beds, $B$. molearni Landes just above the bentonite-rich beds, and $B$. asperiformis Meek in the uppermost part of the formation. The presence of the slightly younger $B$. perplexus Cobban above the bentonite-rich part of the Pembina Member in North Dakota reveals a younger age for the upper part of that member than for the top of the Claggett Shale.

The Sharon Springs and Mitten Black Shale Members of the Pierre Shale in the southern Black Hills region are also dark shales that can be correlated with the Pembina Member by their lithology. The Sharon Springs is a dark-gray fissile shale that resists weathering and tends to form ridges and steep-walled gullies. The shale is organic-rich and contains an abundance of macerated fish remains (notably scales) and shotlike aggregates of pyrite and many beds of medium-bluishgray nonswelling bentonites in the basal part. (For photographs of these bentonites, see Spivey, 1940, pl. opposite p. 24.) After long exposure, the bentonites weather pale yellowish gray to yellowish orange, and the pyrite contained in the shale decomposes to form thin platelike masses of yellow jarosite and limonite. Well-formed transparent selenite crystals are common on some outcrops. The bentonite-rich basal beds contain Baculites obtusus, the middle part contains $B$. mclearni, and the upper part contains $B$. asperiformis. The Mitten Black Shale Member is softer than the underlying Sharon Springs Member, and its organic content is much less. Jarosite and selenite are not as common, and bentonite is scarce. The Mitten grades downward into the Sharon Springs, and the transition 
beds may contain one or more layers of tan phosphate nodules encrusted by white gypsum. B. asperiformis occurs in the basal beds and a smooth unnamed baculite, at a slightly higher level. The upper part of the Mitten contains iron-stained limestone concretions that have numerous $B$. perplexus. The lithology and fossil content of the Mitten suggest a correlation with the upper or bentonite-poor part of the Pembina Member, whereas the bentonite-rich Sharon Springs Member seems to correlate with similar beds in the lower part of the Pembina.

Along the Missouri River valley in south-central South Dakota, deposition was very slow and was interrupted somewhat during the time that the Sharon Springs and Mitten were forming in the Black Hills region. As a result, the equivalent strata along the Missouri River are very thin, and they are customarily treated as a single member of the Pierre Shale. Searight (1938, p. 137) assigned the Kansas name Sharon Springs to them, and this term has been used by all subsequent workers. The member consists of a lower part of dark-gray to brownish-gray resistant shale that contains abundant macerated fish remains and many thin layers of bentonite and a less organic-rich upper part that contains soft phosphatic nodules and possibly no more than two beds of bentonite. (For a photograph of the bentonite-rich part, see Gries and Rothrock, 1941, pl. opposite p. 8.) Colorless selenite and yellow jarosite are common. Most of the member can be easily correlated by its lithology with the Sharon Springs and Mitten of the Black Hills and with the Pembina Member of North Dakota.

The black organic-rich shale in the lower part of the Pembina Member is weakly radioactive, and these beds have easily identifiable electric and gamma-ray curves that provide a reliable stratigraphic datum throughout the subsurface of the central and western Dakotas and eastern Montana and Wyoming. The Pembina Member thickens westward from the Pembina Mountain area, and the equivalent strata in the subsurface in extreme western North Dakota reach a thickness of slightly less than 200 feet (Gill and Cobban, 1961, p. D188, D190, fig $352.3 A$ ). Here, these strata are separated from the Niobrara Formation by 800 to 1,000 feet of shale (Gill and Cobban, 1961, p. D185, D190, fig. $352.2 B$ ). This shale, called the Gammon Ferruginous Member of the Pierre Shale in the Black Hills region (fig. 3), thins eastward across the Dakotas and has not been definitely identified in outcrops of eastern North Dakota. The eastward thinning of the Gammon is due to the increasing distance from the western source and to lateral gradation into and interfingering with the Niobrara Formation (Gill and Cobban, 1961, p. D185).
The thinning is accompanied by a change from a thick sequence of soft bentonitic claystone and shale containing abundant ironstone concretions and a few persistent beds of bentonite to a thin sequence of hard platy brownish-black shale containing thin persistent beds of bentonite. The basal foot or so of the Pembina Member at the Pembina River section may represent a part of the Gammon Ferruginous Member (fig. 5). The Gammon has not been formally recognized in central South Dakota but it may correlate with a thin sequence of beds at the base of the Sharon Springs Member in the Chamberlain, S. Dak., area.

\section{GREGORY MEMBER}

The Gregory Member of the Pierre Shale, as originally defined by Searight (1937, p. 10), included all the strata along the Missouri River in south-central South Dakota between the Niobrara Formation and the base of an ironstone-bearing siliceous shale unit that Searight had named the Sully Member. Searight's original Gregory Member was twofold, consisting of a lower part of "dark, bentonite bearing, bituminous shales which contain numerous fish scales," and an upper part of "a thin but characteristic zone of chalk, chalky shale, argillaceous chalk, or marl." Later Searight (1938, p. 137) restricted the name Gregory to the calcareous beds. Gries and Rothrock (1941, p. 11-14) further altered the scope of the Gregory Member by proposing the name Crow Creek for a thin chalky member at the top of the calcareous unit and restricting the Gregory to a partly calcareous shale that underlies the Crow Creek. This partly calcareous shale unit had been included in Searight's original Gregory Member but was assigned to the uppermost part of the Sharon Springs Member in his 1938 revision. Gries and Rothrock's interpretation of the Gregory has been accepted by all subsequent authors. The member is best exposed in the Chamberlain, S. Dak., area where Gries and Rothrock (1941, p. 12-13) determined thicknesses as great as 125 feet and described the member as

light buff to dark gray when fresh, and from light brown to gray when weathered. Outcrops are typically banded with alternate beds of dark gray, noncalcareous shale containing brown ironstone concretions, and light-gray to buff calcareous layers. These calcareous layers range from slightly calcareous shale to impure chalk and limestone in composition, and from a few inches to several feet in thickness. $* *$ A conspicuous feature of all exposures of Gregory shale is an abundance of brown, fossiliferous concretions. These range from two to six or more inches in thickness, and may be small and intermittent, or may form nearly continuous ledges. Zones of large, one to two foot, gray limestone concretions are also present in some exposures. 
L. G. Schultz (oral commun., 1964), who studied the Gregory Member in the Chamberlain area, found that this description applies only to the lower one-half or two-thirds of the member, and that the upper part of the member is lighter colored, bentonitic, and noncalcareous and lacks limestone concretions.

Fossils are common in the lower or calcareous part of the Gregory Member; they are pyritic in fresh roadcuts and streambanks, and dark brown and limonitic on weathered outcrops. Many of Meek and Hayden's types came from this part of the member. Baculites gregoryensis Cobban characterizes the lower part of the calcareous beds, and $B$. scotti Cobban marks the upper part (fig. 3). We collected $B$. gregoryensis as low as 2 feet above the base of the member in the Chamberlain, S. Dak., area. Megafossils have not been found in the upper or bentonitic part of the Gregory in the Chamberlain area. This part must lie in the Range Zone of $B$. scotti or in a younger range zone. The presence of bentonite suggests a range zone above that of $B$. scotti inasmuch as bentonite is absent in rocks of $B$. scotti age in the Black Hills area. Rocks lying in the next younger Range Zone of Didymoceras nebrascense are very bentonitic in east-central Montana and partly bentonitic on the north flank of the Black Hills. The upper part of the Gregory Member probably lies in this range zone.

In eastern North Dakota a unit of light-colored calcareous strata overlying the dark noncalcareous Pembina Member is assigned herein to the Gregory Member. These calcareous rocks are most typical and best exposed in the valley of the Sheyenne River at Valley City and southward for at least 20 miles. The rocks were originally described by Leonard (1904, p. 152 ) as a light-gray calcareous clay shale 100 feet thick of which the upper part was cream colored and more calcareous than the lower part. Leonard noted that the calcareous rocks were overlain by 10 to 20 feet of black clay shale which was more fissile. Later Leonard $(1906$, p. 69,73$)$ believed that this black shale was the same as the basal black shale member of the Pierre Shale in the Pembina Mountain area; and, accordingly, he assigned the underlying lightcolored calcareous strata at Valley City to the Niobrara Formation. This change in assignment was followed also by Babcock and Clapp (1906, p. 103, 106). At a much later date, Leonard $(1919$, p. 8$)$ still assigned this calcareous unit to the Niobrara, and noted that it contained 45 percent of carbonate of lime at Valley City (erroneously reported as 75 percent in his 1904 paper, p. 152). Much later Kline (1942, p. $355)$ correctly assigned this calcareous unit to the
Pierre Shale, and she stated that it "may be equivalent to the chalk in the upper Gregory of South Dakota."

We measured a complete section of the Gregory Member near Little Yellowstone Park (fig. 2A, loc. 5) where it is well exposed along North Dakota Highway 46 in the Sheyenne River valley about 20 miles south of Valley City in sec. 31, T. 137 N., R. 57 W. and secs. 35 and 36, T. 137 N., R. 58 W. (See Little Yellowstone Park section, units 14-23.) Here the member is 108 feet thick and divisible into a lower 53-foot unit of calcareous and noncalcareous shale containing yellowishbrown ironstone concretions and an upper 55-foot unit of marlstone. The lower or shale unit forms a banded outcrop owing to an alternation of darker weathering noncalcareous or slightly calcareous beds and lighter weathering more calcareous beds (fig. 7). The upper or marlstone unit is pale yellowish gray and grades down into the lower unit. The member rests with sharp contact on the underlying Pembina Member, and the contact is marked by local accumulations of a darkyellowish-orange to black mixture of gypsum, limonite, and manganese oxides.

Fossils are present, although not common, in the Gregory Member in the measured section. Unweathered ammonites are pyritic, whereas weathered ones are limonitic and dark brown. Baculites gilberti Cobban, which marks the middle of the Range Zone of $B$. perplexus, was found 10 feet above the base; and undescribed scaphites suggestive of the Range Zone of $B$. perplexus, were found as high as 32 feet above the base. $B$.gregoryensis, an index fossil for the next range zone in the western interior above that of $B$. perplexus, was collected 49 feet above the base, and juvenile baculites that may be this species were found as high as 67 feet above the base. Some part or all of the rest of the upper marlstone unit probably lies in the Range Zone of $B$. scott $i$ judging from impressions of an undescribed species of the aberrant ammonite Didymoceras collected by members of the Department of Geology of the University of North Dakota from an outcrop of this marlstone at the north edge of North Valley City. This ammonite closely resembles specimens that have been found elsewhere in the western interior only with $B$. scotti.

H. A. Tourtelot collected samples from units $1,2,5$, and 6 of the Gregory Member of the Pierre Shale near North Valley City. (See North Valley City section.) These and additional samples collected by L. G. Schultz from the Crow Creek and Gregory Members of the Pierre in central South Dakota were examined for 


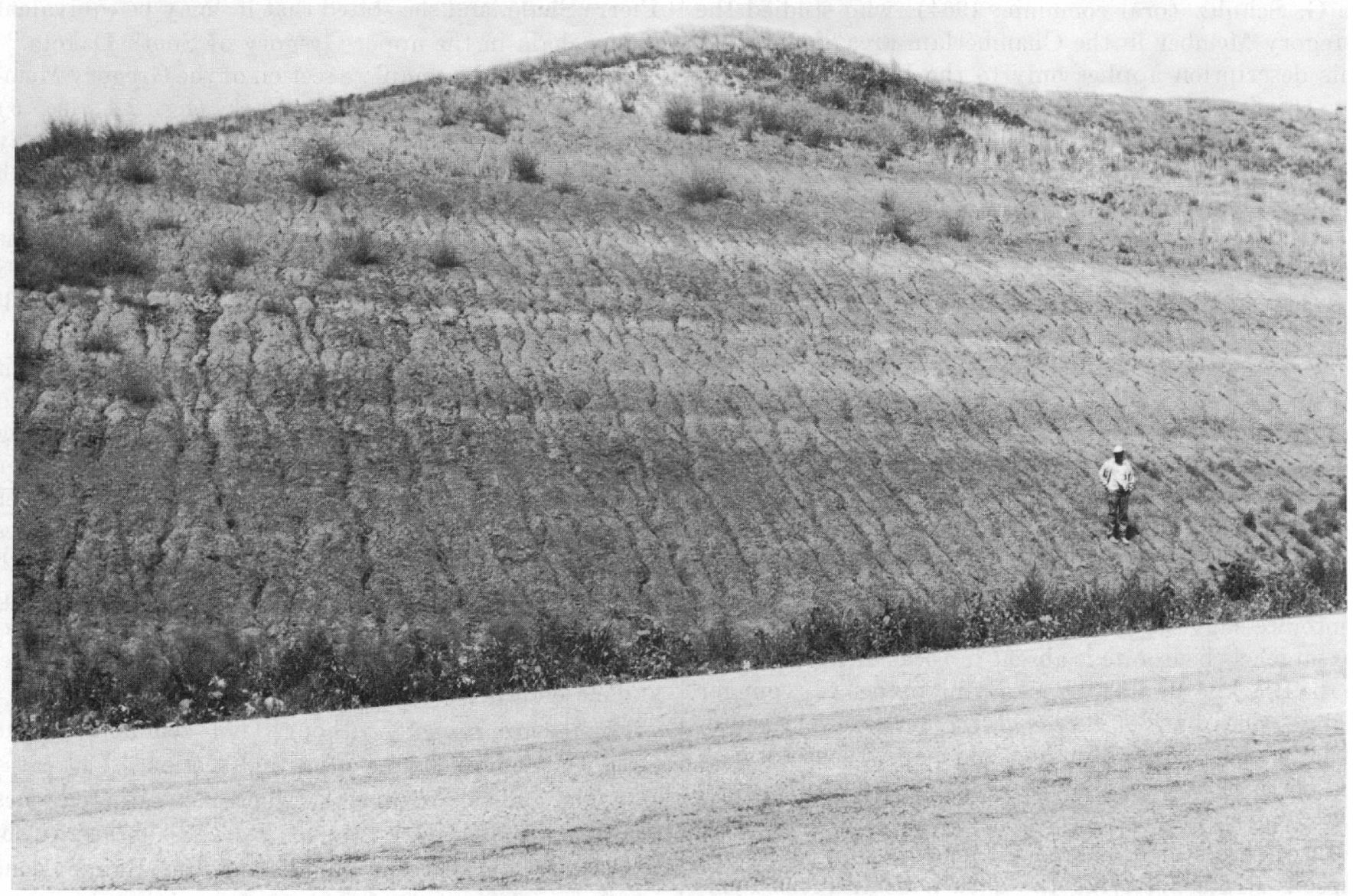

Figure 7.-Pierre Shale exposed in roadcut of North Dakota Highway 46 on the east side of the Sheyenne River in the SW $1 / 4$ SW $1 / 4$ sec. 31, T. 137 N., R. 57 W., Barnes County, N. Dak. Man is standing on a manganese-limonite bed that marks the contact between the Pembina Member (dark), and the Gregory Member (banded, light and dark). (See Little Yellowstone Park section.) Light (calcareous) and dark (less calcareous or noncalcareous) bands are typical of the lower part of the Gregory in both North and South Dakota.

Foraminifera by James F. Mello of the Geological Survey who reported the presence of the following fossils (written commun. to H. A. Tourtelot, Mar. 26, 1963) :

Sample To57-31-6

[20 ft below top of Gregory Member, North Valley City]

Allomorphina conica Cushman and Todd

Ammodiscus cretaceus (Reuss)

Anomalina henbesti Plummer

Planomalina (Globigerinelloides) messinae (Bronimonn)

Bolivina cf. B. incrassata Reuss

Bolivinitella elevi (Cushman)

Bolivinoides decorata (Jones)

Bolivinopsis rosula (Ehrenberg)

Bulimina kickapooensis Cole

reussi Morrow navarroensis Cushman and Parker

Cibicides cf. C. harperi (Sandidge) ?

Dentalina niobrarensis Loetterle?

cf. D. legumen (Reuss)

graculis d'Orbigny

consobrina d'Orbigny
Entosolenia orbignyana (Seguenza)

Eouvigerina gracilis Cushman

Globorotalites subconicus (Morrow)

Gyroidina depressa (Alth)

globosa (Hagenow) of Cushman

Haplophragmoides sp.

Hedbergella loetterlei (Nauss)

Heterohelix globulosa (Ehrenberg) pulchra (Brotzen)

Loxostoma plaitum (Carsey)?

Neobulimina canadensis Cushman and Wickenden

Nodosaria cf. $N$. alternistriata Morrow

Nuttallinella? n. sp.

Oolina n. sp.

Pleurostomella subnodosa Reuss

Quadrimorphina allomorphinoides (Reuss)

Ramulina globo-tubulosa Cushman

Schackoina multispinata Cushman

Stensioina americana Cushman and Dorsey

Stilostomella pseudoscripta (Cushman)

Valvulineria infrequens Morrow 
Sample To57-31-5

[40 ft below top of Gregory Member, North Valley City]

Allomorphina conica Cushman and Todd

Ammodiscus oretaceus (Reuss)

Planomalina (Globigerinelloides) messinae (Bronnimann)

Bolivinopsis rosula (Ehrenberg)

Bulimina kickapooensis Cole

reussi Morrow navarroensis Cushman and Parker

Caucasina vitrea (Cushman and Parker)

Dentalina cf. D. legumen (Reuss)

Eouvigerina gracilis Cushman

Globorotalites subconicus (Morrow)

Gyroidina depressa (Alth)

globosa (Hagenow) of Cushman

Haplophragmoides sp.

Hedbergella loetterlei (Nauss)

Heterohelix globulosa (Ehrenberg) pulchra (Brotzen)

Neobulimina canadensis Cushman and Wickenden (typical form) canadensis (new form) (?)

Nodosaria fusula Reuss

Nuttallinella? n. sp.

Oolina n. sp. (?)

Osangularia navarroana (Cushman)

Pleurostomella subnodosa Reuss

Pseudouvigerina cretacea Cushman

Quadrimorphina allomorphinoides (Reuss)

Stilostomella pseudoscripta (Cushman)

Sample To57-31-2

[100 ft below top of Gregory Member, North Valley City]

Ammodiscus cretaceus (Reuss)

Anomalinoides $\mathrm{n}$. sp.

Planomalina (Globigerinelloides) messinae (Bronnimann)

Bolivinopsis rosula (Ehrenberg)

Bulimina kickapooensis Cole

reussi Morrow navarroensis Cushman and Parker

Caucasina vitrea (Cushman and Parker)

Dentalina cf. D. gracilis d'Orbigny

Entosolenia cf. E.orbignyana (Seguenza)

Eouvigerina gracilis Cushman

Globorotalites subconicus (Morrow)

Glomospira charoides (Jones and Parker)

Gyroidina depressa (Alth)

globosa (Hagenow) of Cushman

Haplophragmoides sp.

Hedbergella loetterlei (Nauss)

Heterohelix globulosa (Ehrenberg)

pulchra (Brotzen)

Neobulimina canadensis Cushman and Wickenden

Nuttallinella? n. sp.

Quadrimorphina allomorphinoides (Reuss)

Stilostomella pseudoscripta (Cushman)

Valvulineria infrequens Morrow

\section{Sample To57-31-1}

[115 ft below top of Gregory Member, North Valley City]

Ammodiscus cretaceus (Reuss) (?)

Bathysiphon sp.

Planomalina (Globigerinelloides) messinae (Bronnimann)

Bulimina kickapooensis Cole.

Gaudryina cf. G. bentonensis (Carman)

Gyroidina depressa (Alth)
Haplophragmoides sp.

Heterohelix globulosa (Ehrenberg)

Stilostomella pseudoscripta (Cushman)

Mello's study of the Forminifera from the Gregory Member at Valley City was undertaken at a time when the stratigraphic position and age of these beds was uncertain. In his report he concluded:

To sum up, the Valley City samples are probably equivalent or very nearly so with the Gregory and Crow Creek samples. They are all of Tayloran age. The Mobridge in north-central South Dakota is of Navarroan age and differs subtly but significantly from the Valley City samples. The Valley City, Gregory, Crow Creek and calcareous Mobridge beds are similar in gross faunal aspect (excepting To57-31-1) and were probably deposited under similar conditions.

There are several exposures of the upper part of the Gregory in the immediate vicinity of Valley City. Leonard (1904, p. 152) described a small outcrop of Gregory along the Soo Railroad about 11/4 miles east of Valley City and mentioned other exposures of the member along the Sheyenne River a mile south of Valley City. The Gregory Member of the Valley City area appears to be about the same thickness and composition as farther south along the Sheyenne River. H. A. Tourtelot supplied us with a section of the Gregory that he measured about half a mile north of North Valley City. (See North Valley City section.) The lower part of the member is poorly exposed and the position of the contact with the underlying Pembina Member could not be accurately determined.

The Gregory Member thins northward from Valley City and becomes less calcareous. It is only 24.5 feet thick in the measured section near the Tongue River (Pembina Mountain section, unit 32), where the member consists of alternate bands of light-colored calcareous claystone and darker colored noncalcareous shale. Thin beds of brown-weathering ironstone are present, but fossils were not observed in them.

The member in these areas can be readily correlated with the Gregory Member of south-central South Dakota by its lithology and fossil content. The lower part of the member near Valley City is, however, a little older than the oldest beds in South Dakota. The general relations of the Gregory Member of South Dakota to the Red Bird Silty Member of the Pierre Shale in the Black Hills region and to the Judith River Formation of Montana have already been shown (Gill and Cobban, 1961, fig. 352.4; 1962, fig. 8.1). The Gregory Member at Valley City seems to be the time equivalent of the Red Bird Silty Member. The base of both units lies well within the Range Zone of Baculites perplexus and the upper part of each unit lies in the Range Zone of B. scotti. 
In the Pembina Mountain area in southern Manitoba, the strata overlying the Pembina Member of the Vermilion River Formation are called the Riding Mountain Formation, which is divided into a lower soft member termed the Millwood Beds and an upper hard member known as the Odanah Beds (Tovell, 1948, p. 2; Halstead, 1959 , p. 9 ; Davies and others, 1962, p. 145). The Millwood Beds in this area had earlier been called the Riding Mountain Beds by Kirk (1930, p. 124B-126B), who described the unit as greenish-gray noncalcareous shale that slumped easily and weathered readily to mudcracked surfaces bare of vegetation. Kirk noted further that nodules and irregular bands of dark-brown ironstone were abundant. He did not determine the thickness near the international boundary, but MacLean (1916, p. 131), who applied the name Millwood (Tyrrell, 1890, p. 230) to these beds, gave a thickness of 80 feet. Tovell $(1948$, p. 5) stated that the thickness in this area ranges "from 15 feet (?) on the west to 65 feet or more in the eastern sections, but no direct measurements were possible."

We briefly examined the Millwood near Miami, Manitoba, in the Pembina Mountain area as well as in the type area around Millwood and Harrowby some 170 miles farther northwest. Near Miami the lowest part of the Millwood is slightly calcareous; and, although no fossils were noted, it seems reasonable to correlate it with the Gregory Member. Fossils found in the lower part of the Millwood in the Millwood-Harrowby area include Baculites scotti, B. gregoryensis, and scaphites suggestive of the $B$. perplexus Range Zone. A correlation of this part of the Millwood with the Gregory Member in North Dakota is unquestioned.

\section{DeGREY MEMBER}

Crandell (1950, p. 2341) proposed the name DeGrey Member for a gray noncalcareous bentonite-bearing unit of the Pierre Shale that contains numerous iron-manganese carbonate concretions. The member was named for a locality near the Missouri River in south-central South Dakota, where the unit is about 82 feet thick and rests conformably on the marly Crow Creek Member. Several of the beds of bentonite contain flakes of biotite, and two of these have proved very useful for correlation along the Missouri River (Gries, 1940, p. 18-27; 1942 , p. 21; Gries and Rothrock, 1941, p. 22-26). A striking feature of the member is the great abundance of black-weathering iron-manganese carbonate concretions which darken the outcrops. Fragments of pelecypods and ammonites are common in these concretions. Bits of baculites indicate a large compressed species that has a well-ribbed venter and a complex suture pattern; these features suggest either Baculites rugosus Cobban or a closely related ventral-ribbed species which mark the Range Zones of Exiteloceras jenneyi (Whitfield) and Didymoceras cheyennense (Meek and Hayden) respectively (fig. 3).

Dark-colored rocks of DeGrey lithology are typical and well exposed along the Sheyenne River valley in North Dakota where they rest upon light-colored calcareous rocks as they do in South Dakota. The name DeGrey is herein applied to these rocks in North Dakota.

The unit was first described by Leonard (1904, p. 152) at Valley City as 10 to 20 feet of "Black clay shale, with yellow iron stains in spots and blotches. Upon exposure to the weather it crumbles into thin flakes." Later Leonard (1906, p. 73) and Babcock and Clapp $(1906$, p. 103, 106) believed that this dark unit was the same as the "banded black and white shale" (Pembina Member) at the base of the Pierre Shale in the Pembina Mountain area.

We did not measure a complete section through the DeGrey Member in the Sheyenne River valley, but the thickness there is at least 40 feet. The member consists of dark flaky bentonitic shale weathering to a dark gumbo bare of vegetation. Black-weathering concretions of iron-manganese carbonate are abundant, and these contain fragments of fossils as they do in South Dakota. A collection made from these concretions 25 to 40 feet above the base of the member 9 miles south of Valley City in the SW1/4 SE1/4 sec. 4, T. $138 \mathrm{~N}$., R. $58 \mathrm{~W}$. contained Inoceramus cf. I nebrascensis Owen, Inoceramus aff. I. molearni Douglas, Pteria n. sp., Ostrea cf. O. plumosa Morton, Ostrea sp., Anomia ef. A. argentaria Morton, Pholadomya hodgei (Meek), and Baculites sp. All of these species occur in the black iron-manganese carbonate concretions in the DeGrey Member at Chamberlain, S. Dak. The few fossils recorded by Upham (1895, p. 92) 8 miles south of Valley City probably came from the DeGrey Member.

The member thins northward and becomes lighter in color. Near the Tongue River it consists of about 30 feet of gray to olive-gray shale and claystone that weathers light gray and contains ironstone concretions weathering reddish brown, dark brown, or black. A conspicuous feature is the presence, at the top of the member, of a layer of partly swelling bentonite containing black flakes of biotite. Fossils are scarce, and only bits of Inoceramus were noted. The member seems to rest conformably on the calcareous Gregory Member and is conformably overlain by siliceous shale herein assigned to the Odanah Member.

Barry and Melsted (1908, p. 180) measured a 280 foot section of the Pierre Shale along the South Branch of the Park River in northern Walsh County, N. Dak. We interpret unit 1 of their section as representing the upper 30 feet of the DeGrey, and the over- 
lying 150 feet of hard shale (their unit 2) as representing the Odanah Member.

The DeGrey Member in the Valley City area is the lithologic continuation of the DeGrey Member of South Dakota. Along the Tongue River the member has changed to a lithology more like that of the upper part of the Millwood Beds in the adjoining part of Manitoba. However, inasmuch as the member along the Tongue River overlies the Gregory Member and still has some DeGrey features such as bentonitic beds and black ironstones, it seems best to apply the name DeGrey as far north as the international boundary rather than use some other term such as upper part of Millwood Beds or to introduce a new name. In the MillwoodHarrowby area of Manitoba, the uppermost part of the Millwood Beds is darker and more bentonitic and gumbo forming than the underlying part. Diagnostic fossils were not found by us in this part, but the presence of baculites of late Gregory age (Range Zone of Baculites scotti) lower in the Millwood suggests that the upper part of the member could well be of DeGrey age.

The DeGrey Member in North Dakota probably correlates with both the DeGrey and Crow Creek Members in the Missouri River valley of South Dakota. The Crow Creek conformably underlies the DeGrey, whereas it apparently disconformably overlies the Gregory Member (Crandell, 1952). The only fossils known from the upper part of the Gregory Member in both North and South Dakota lie in the Range Zone of Baculites scotti. This similar dating of the upper part of the Gregory in both areas and the apparent hiatus separating the Crow Creek from the Gregory make it more logical to assume that the lower part of the DeGrey Member in North Dakota is the time equivalent of the Crow Creek.

The presence of Baculites scotti in the uppermost part of the Red Bird Silty Member of the Pierre Shale in the Black Hills area shows that the DeGrey Member is the time equivalent of a part of the overlying unnamed shale member which contains baculites having corrugated venters suggestive of the fragments in the DeGrey Member at Chamberlain, S. Dak. Similar baculites are present in the lower part of the Bearpaw Shale south of the Bearpaw Mountains in central Montana. Accordingly, the DeGrey Member is correlated with the lower part of the Bearpaw Shale and with the lower part of the unnamed shale unit that overlies the Red Bird Silty Member of the Pierre Shale (fig. 3).

Beds equivalent to the DeGrey have wide distribution in southwestern Manitoba. Near the SaskatchewanManitoba line, some 250 miles north of the international boundary, bentonitic claystone and shale containing abundant iron-manganese nodules, were described by Dawson (1942, p. 10-11) as follows:

The nodular deposits [iron-manganese] of Porcupine Mountain area have an interesting similarity in stratigraphical position, lithology and manganese content to those of the lower Missouri Valley in South Dakota. In the latter area manganiferous nodules occur in the Oacoma zone of the Sully shale member [DeGrey Member] which is a subdivision of the South Dakota Pierre. The Pierre in Manitoba includes the upper part of the Vermilion River formation, the Riding Mountain [Millwood] formation and the Odanah formation. The stratigraphical position of the known manganiferous horizon or horizons in the Riding Mountain [Millwood] formation is, further, similar to the position of the Oacoma zone in the Pierre of South Dakota.

\section{ODANAH MEMBER}

Tyrrell $(1890$, p. 230$)$ gave the name Odanah Series to "a great thickness of light gray rather hard clay shales which are locally known as slate." The Odanah overlies the softer dark-gray clay shale unit which Tyrrell had named the Millwood Series. The name Odanah was taken from a locality near Minnedosa, Manitoba, about 85 miles north of the North Dakota boundary. MacLean (1916, p. 131) applied the name Odanah to the hard light-colored shale above the soft Millwood Beds in the Pembina Mountain area. Wickenden $(1945$, p. 48$)$ believed the Odanah to be only a poorly defined hard facies of the Riding Mountain Formation, but Tovell (1948, p. 6), Halstead (1959, p. 9-10), and Davies and others $(1962$, p. 145) treated the Odanah as a distinct member.

The Odanah, along the Pembina River a few miles north of the North Dakota boundary, was described by Tovell (1948) as chiefly hard gray siliceous shale that has a greenish cast and contains some thin beds of bentonite, of which a layer 0.8 foot thick near the base is a persistent marker bed. Some softer bentonitic shale is interbedded with the hard siliceous shale. Tovell noted further that the shale showed purple staining as well as limonitic staining and that irregularly distributed purple-stained concretions were common.

In the Pembina Mountain area of North Dakota, the soft DeGrey Member is overlain conformably by hard light-gray siliceous shale that contains ferruginous concretions. This hard shale is obviously the southward continuation of the Odanah Beds, and the name Odanah is herein used as a member of the Pierre Shale. Outcrops of this member in the Pembina Mountain area have been described by Upham (1895, p. 93-96) and Barry and Melsted (1908, p. 180-183), who observed the slatelike character of the shale, the iron-stained joint surfaces, and the abundance of ferruginous concretions. Barry and Melsted also recorded a persistent 1-foot layer of yellow clay [bentonite] in the lower part of the member. This bed may be the same as the widespread 0.8- 
foot bentonite noted by Tovell $(1948$, p. 6$)$ farther north.

The thickness of the Odanah Member in the Pembina Mountain area of North Dakota is largely unknown. The lower 65 feet can be seen along North Dakota Highway 5 near the Tongue River. (See Pembina Mountain section, unit 36.) Barry and Melsted (1908, p. 180) measured 150 feet of hard shale along the South Branch of the Park River in northern Walsh County which we interpret as representing the Odanah Member in this area. Farther north, about 200 feet of the member is present in the Manitoba part of Pembina Mountain (Tovell, 1948, p. 6). Outcrops of the member in North Dakota outside the Pembina Mountain area are scarce, and the thickness of beds exposed at most places is small. One of the largest outcrops, in the Devils Lake area (fig. 1), shows only 20 feet of beds (Laird, 1957, pl. 1). A cursory examination of logs of oil and gas test wells in northern North Dakota suggests that the Odanah may reach a thickness of about 200 feet in eastern Rolette County, from where it appears to thin abruptly to the west.

Fossils in the Odanah are scarce, and little is known concerning the time range of the member. Wickenden (1945, p. 49-50) mentioned the occurrence of numerous radiolarians, and listed the foraminifers Glomospira charoides (Jones and Park) var. corona Cushman and Jarvis, Ammodiscus cretacea (d'Orbigny), Bigenerina hastata Cushman, and Silicosigmoilina californica Cushman and Church; the pelecypods Oxytoma nebrascana Evans and Shumard and Ostrea sp.; the cephalopods Scaphites (Discoscaphites?) sp. and Baculites compressus Say; and the calcareous worm tube Serpula sp. Three species of pelecypods-Leda hindi, Inoceramus canadensis, and Anomia flemingi-described by Meek (1860, p. 196, pl. 1, figs. 2-5, 8-9) from southern Manitoba probably came from low in the Odanah. The only fossils we observed in North Dakota were bits of Inoceramus. Upham (1895, p. 94) recorded I. sagensis Owen, Baculites ovatus Say, Scaphites nodosus Owen, and fish teeth from the Pembina Mountain area. The presence of radiolarians, presumably from this part of the Pierre Shale, was mentioned by Holland (1961, p. 59).

Part of the Odanah grades southward into the Virgin Creek Member of the Pierre Shale of South Dakota ("lower Virgin Creek" of Searight, 1937, p. 36). In south-central South Dakota the Virgin Creek is a soft medium-gray flaky shale that contains several thin layers of bentonite. Farther north the member becomes harder and lighter colored; and at its type locality 18 miles southwest of Mobridge, part of the member, as described by Searight (1937, p. 39), is "light gray, erodes first to buttresses with red to rusty brown coat- ing. Later breaks down to gentle shopes. Where recently undercut breaks into flattish pieces which produce dull slaty 'clink' when struck. Later breaks down to flakes which have a faint purplish cast which produces a sub-metallic sheen. Contains 11 thin bentonite beds ***" Rothrock (1947, p. 12) also noted the northward change of the Virgin Creek from nonsiliceous to siliceous shale. The Virgin Creek is separated from the DeGrey Member by the Verendrye Member, a gray shale that weathers to bands of brown and gray gumbo and contains numerous flattish brown-weathering ironstone concretions. Both the Verendrye and the lower part of the Virgin Creek Members are probably equivalent to the Odanah (fig. 3). The Virgin Creek contains Baculites eliasi Cobban. The Verendrye may include more zones although the best fossils found so far are poorly preserved fragments of baculites suggesting B. cuneatus Cobban.

The upper part of the Virgin Creek is a bentonitic shale unit that readily forms a bare gumbo. This unit was called "upper Virgin Creek" by Searight (1937, p. 37), but later Rothrock (1947, p. 11) assigned most or all of it to the overlying calcareous Mobridge Member. Rothrock's assignment of Searight's "upper Virgin Creek" to the Mobridge has not gained wide acceptance, and most recent workers have followed Searight's original treatment.

The Kara Bentonitic Member and the uppermost part of the underlying unnamed shale member of the Pierre Shale in the southwestern Black Hills region contain Baculites eliasi Cobban and correlate with the lower part of the Virgin Creek Member. This ammonite is also found high in the Bearpaw Shale of central Montana. By inference, the upper part of the Odanah may correlate with this part of the Pierre and Bearpaw Shales, whereas the rest of the Odanah may correlate with the middle part of the Bearpaw and most of the upper half of the unnamed shale member of the Pierre underlying the Kara Bentonitic Member.

The upper part of the Pierre Shale has been largely removed from eastern North Dakota by pre-Pleistocene erosion, and outcrops of Cretaceous rocks younger than the Odanah Member were not seen by us. Barry and Melsted (1908, p. 180) reported that on the South Branch of the Park River in northern Walsh County 10 to 100 feet of dark fissile shale that weathers to a black sticky clay overlies beds which we interpret as Odanah. These shales may be equivalent to the upper part of the Virgin Creek Member of the Pierre Shale.

The original thickness of the Pierre in eastern North Dakota is unknown, but an extrapolation of rates of eastward thinning of the Pierre in the central and western parts of the State suggests that between 500 and 600 feet of beds may have been deposited. The 
thickness and distribution of the marine Cannonball Member of the Fort Union Formation of Paleocene age in North Dakota and adjacent areas might be interpreted to mean that in the extreme eastern part of the State slow but continuous marine deposition lasted until early Paleocene time.

\section{REFERENCE SECTIONS}

Reference sections of parts of the Pierre Shale were measured in eastern North Dakota. The purpose of these sections is to supplement previously published sections mentioned in the text and to provide a framework for additional stratigraphic studies of the Pierre Shale in eastern North Dakota.

\section{Little Yellowstone Park section}

[Measured In roadcuts along North Dakota Highway 46 near Little Yellowstone Park about 20 miles south of Valley City. Lower part measured in the $S W 1 / 4 \mathrm{SW} 1 / 4$ sec. $31, T$. $137 \mathrm{~N}$., R. $57 \mathrm{~W}$., and the upper part measured in the $S W 1 / 4 \mathrm{SW} 1 / 4$ sec. 36 and $S E 1 / 4 \mathrm{SE} 1 / 4$ sec. 35 T. 137 N., R. 58 W., Barnes County (fig. 2A, loc. 5)]

Pierre Shale (lower part) :

DeGrey Member (part) :

23. Shale, black, noncalcareous, flaky

Gregory Member :

22. Marlstone, pale-yellowish-gray; very clayey and soft at base and top; moderately hard in middle; weathers to a grayish-yellow slope. A few pyritic juvenile baculites collected $13 \mathrm{ft}$ above base; USGS Mesozoic loc. D4098, Baculites ef. B. gregoryensis Cobban

21. Shale, dark-gray, slightly calcareous, flaky; interbedded with a subordinate amount of lighter colored calcareous claystone which imparts a banded appearance to the weathered outcrop. Unit contains thin beds of shaly reddish-brownweathering ironstone. Unit becomes increasingly calcareous upward and grades into the the overlying marlstone. A few small pyritic baculites collected in middle of unit; USGS Mesozoic loc. D4098, Baculites cf. B. gregoryensis Cobban

20. Shale, dark-gray; slightly calcareous becoming more calcareous and lighter gray in upper part. A few fossils collected at 10 and $13 \mathrm{ft}$ above base; USGS Mesozoic loc. D4097, Trachytriton vinculum (Hall \& Meek), Baculites gregoryensis Cobban, Didymoceras sp.

19. Claystone, pale yellowish-brown, very calcareous : weathers to a yellowish-gray soft slope; contains thin beds of yellowish-brown-weathering shaly ironstone. A few fossils collected $3.5 \mathrm{ft}$ above base; USGS Mesozoic loc. D4096, Baculites sp., Hoploscaphites n. sp

18. Shale, olive-gray, noncalcareous to slightly calcareous, flaky ; forms a dark slope; contains thin ironstone beds. A 0.6 - $\mathrm{ft}$ calcareous claystone bed $3 \mathrm{ft}$ above base contains a few fossils; USGS Mesozoic loc. D4095, Inoceramus sp. Baculites sp.
Little Yellowstone Park section-Continued

Pierre Shale (lower part) - Continued

Gregory Member-Continued

17. Claystone; weathers light yellowish gray; very calcareous. Contains a few fossils; USGS Mesozoic loc. D4095, Inoceramus sp., Bacu lites $\mathrm{sp}$

16. Bentonite, orange, deeply weathered; contains abundant limonite and gypsum.

15. Shale; in medium-light-gray calcareous units alternating with medium-dark-gray noncalcareous units; weathers to small soft flakes; contains layers of yellowish-brown ironstone and a few tan phosphate pebbles. Basal $1.5 \mathrm{ft}$ is light-gray very calcareous shale. A few fossils collected at $1 \mathrm{ft}$ and $4.5 \mathrm{ft}$ above base; USGS Mesozoic loc. D4094, Inoceramus sp., Baculites cf. B. gilberti Cobban, Hoploscaphites n. sp-

14. Shale; in medium-light-gray noncalcareous flaky units alternating with medium-dark-gray slightly bentonitic units; contains thin beds of rustyweathering shaly ironstones and scattered small pyrite nodules. A few fossils collected $10 \mathrm{ft}$ above base; USGS Mesozoic loc. D4093, calcareous worm tubes, Baculites gilberti Cobban - -

Total Gregory Member

Pembina Member:

13. Nonpersistent layer of a mixture of gypsum, limonite, and manganese oxides

12. Shale, grayish-brown to brownish-black; weathers to light-olive-gray thin flakes; contains a few scattered gypsum-encrusted phosphate nodules in upper $3 \mathrm{ft}$. Unit is slightly harder than underlying beds.

11. Bentonite, very pale orange, nonswelling; contains numerous weathered pyrite nodules.....-.

10. Shale, similar to unit 12 but containing abundant streaks of yellowish-orange jarosite; contains a thin layer of limonitic bentonite $8 \mathrm{ft}$ above base. Unit contains persistent beds of gypsumencrusted phosphate nodules at 2.6, 3.4, and $4.6 \mathrm{ft}$ above base, and 4 layers of phosphate nodules in upper $5 \mathrm{ft}$

9. Ironstone, dark-yellowish-orange, slabby--_-_--

8. Shale, similar to unit 10 ; contains gypsum-encrusted phosphate nodules, large gypsum-encrusted bones, and gypiferous limonitic baculites at $8 \mathrm{ft}$ and $13 \mathrm{ft}$ above base. One pyritic baculite collected $14 \mathrm{ft}$ above base; USGS Mesozoic loc. D4092, Baculites perplexus Cobban

7. Bentonite, very pale orange, nonswelling------- $\quad 0.1$

6. Shale, similar to unit 10

5. Bentonite, similar to unit 7

Total Pembina Member-_-

Total Pierre Shale measured

eet

$=$


Little Yellowstone Park section-Continued

Niobrara Formation (uppermast part)

4. Shale, medium yellowish-brown, calcareous; cemented with gypsum and jarosite

3. Chalk, rery pale orange, hard

2. Covered interval; probably soft chalk

1. Chalk, dark-yellowish-orange to pale-yellowishorange

Total Niobrara Formation measured

\section{North Valley City section}

[Measured in 1957 by $H$. A. Tourtelot in roadcut half a mlle north of North Valley City, just north of road to east, and along this road to the east in the NE1/4 sec. 9, T. 140 N., R. 58 W., Barnes County (fig. 2A, loc. 4)]

Pierre Shale (lower part) :

DeGrey Member (part) :

7. Shale, dark-gray, soft, highly bentonitic; has a flaky fracture; weathers to a black 0.5-ft thick gumbo that contains abundant selenite. Blackweathering concretions of iron-manganese carbonate containing fragments of Inoceramus are moderately abundant. Unit is at least 50 ft in total thickness (estimated from outcrops across valley to south)

Gregory Member (part) :

6. Chalk and clayey chalk, gray ; forms steep slope in roadcut; weathers tan to creamy yellow.-

5. Shale, gray, marly, bentonitic, soft; weathers bluish gray

4. Chalk and marly chalk; gray; weathers tan; much ferruginous debris on surface

3. Covered interval

2. Marly chalk; grayish-buff; ferruginous debris scattered on surface; joint planes stained with manganese oxide.

1. Shale, dark-gray, calcareous, bentonitic, soft; flaky fracture; weathers to a 0.5 -ft thick grayish-brown gumbo that contains much ferruginous debris; iron oxides and scattered minute selenite crystals coat joint planes. Base not exposed

Total Gregory Member exposed

Total Pierre Shale measured

\section{Pembina Mountain section}

[Beds 1-27 measured by $H$. A. Tourtelot on the Olson Farm in the NE $1 / 4$ sec. 25, T. 161 N., R. 57 W. (fig. 2B, loc. 3A) ; beds 28-36 measured by J. R. Gill at the splllway cut for the Tongue River retention dam $\mathrm{T}-3-5$ in the SE $1 / 4$ NE $1 / 4$ sec. 24, and along North Dakota Highway 5 in the $\mathrm{NW} 1 / 4 \mathrm{NE} 1 / 4$ sec. 24 , T. 161 N., R. 57 W. Cavalier Counts (flg. 2B, loc. 3b) ]

Pierre Shale (lower part) :

Odanah Member (part) :

36. Shale, medium-light-gray to light-gray, siliceous, hard ; weathers to thin angular chips; contains a few thin ironstone concretions in lower part. Thickness determined by altimeter
Pembina Mountain section-Continued

Pierre Shale (lower port)-Continued

DeGrey Member :

35. Bentonite, light-olive-gray ; slightly swelling ; contains numerous black euhedral crystals of biotite in lower $0.1 \mathrm{ft}$

34. Shale, olive-gray; weathers light gray; lower 5 ft soft, but rest of unit hard and tends to form ridges. Unit contains several thin layers of reddish-brown-weathering ironstones. Fragments of Inoceramus common $15 \mathrm{ft}$ above base-- 23.0

33. Claystone, gray, noncalcareous, bentonitic ; weathers to light-gray gumbo barren of vegetation; contains a few small dark-brown to black ironstone concretions that weather into small angular fragments

Total DeGrey Member

Gregory Member :

32. Claystone and shale; interbedded to form a light and dark banded outcrop. Dark layers consist of olive-gray noncalcareous shale that weathers to a lighter flaky crust. Light layers consist of light-olive-gray calcareous bentonitic claystone that weathers to pale-yellowish-brown gumbo. A 2-ft-thick yellowish-gray-weathering very calcareous claystone bed $13 \mathrm{ft}$ above base and a 0.2 ft-thick cream-colored slightly swelling bed of bentonite $2 \mathrm{ft}$ above base. Unit contains numerous thin beds of light-brown-weathering ironstone

Pembina Member :

31. Shale, dark-gray; weathers to light-olive-gray thin plates; fish scales and jarosite seams less abundant than in underlying unit. Numerous gypsum-encrusted phosphate nodules in upper $15 \mathrm{ft}$, and tan phosphate nodules in upper 2 ft. Very thin layers of dark-yellowish-brown limonite and jarosite impregnated bentonite at $7,27,30.3$, and $32 \mathrm{ft}$ above base

30. Bentonite, pale-yellowish-gray, nonswelling

29. Shale, dark-brownish-black; weathers to olivegray thin plates; contains abundant fish scales, seams of jarosite, and plates of selenite; becomes harder and more organic rich in lower part. A 0.05-ft-thick layer of bentonite $29 \mathrm{ft}$ above base.

28. Bentonite, yellowish-orange, nonswelling, granular

27. Shale, biack; weathers to light-gray flakes $5 \mathrm{~mm}$ or more in diameter; organic rich.

26. Bentonite, similar to unit 24-(- 02

25. Shale, similar to unit 27-_- .4

24. Bentonite, creamy-tan, nonswelling, granular; irregular conchoidal fracture; tastes acidic _-_ . .4

23. Shale, similar to unit 27

22. Bentonite, similar to unit 24

21. Shale, similar to unit 27

20. Bentonite, similar to unit 24_-_-_-_-_-_--- . 2

19. Shale, similar to unit 27 . 
Pembina Mountain section-Continued

Pierre Shale (lower part) - Continued

Pembina Member (part) - Continued

18. Bentonite, similar to unit 24

17. Shale, similar to unit 27

16. Bentonite, similar to unit 24

15. Shale, similar to unit 27

14. Bentonite, similar to unit 24 ; contains irregular tubelike masses of gray shale $1 \mathrm{~mm}$ in diameter and as much as $20 \mathrm{~mm}$ in length in upper 0.1 ft

13. Shale, similar to unit 27

12. Bentonite, similar to unit 24

11. Shale, similar to unit 27

10. Bentonite, similar to unit 24

9. Shale, similar to unit 27

8. Bentonite, similar to unit 24

7. Shale, similar to unit 27

6. Bentonite, similar to unit 24

5. Shale, similar to unit 27

4. Bentonite, similar to unit 24 but has grayish cast

3. Shale, similar to unit 27 but contains noticeable pyrite

2. Bentonite, similar to unit 24 but has irregular fracture coating of yellow highly plastic clay.-

1. Shale, similar to unit 2

Total Pembina Member (rounded) $-75.0$

Total Pierre Shale measured

Iron oxide in irregular crust; appears to have been formed on present outcrop cementing basal shale of Pierre and uppermost chalky marl of the underlying Niobrara Formation into a beterogeneous ledge Niobrara Formation:

Chalky marl and chalk. Forms cliff. Not measured.

\section{Pembina River section}

[Partial section of the Pembina Member of the Plerre Shale measured by $J$. $R$. Gill and $W$. A. Cobban in a roadcut west of the Pemblna River in the $S W 1 / 4$ sec. $30, T$. 163 N., R. 57 W., Cavalier County (fig. $2 B$, loc. 2 )

Pierre Shale (part) :

Pembina Member (part) :

35. Shale, dark-brownish-black ; hard, forming a buttress ; contains abundant fish scales and numerous streaks of yellowish-orange-weathering jarosite -

34. Bentonite, pale-yellowish-orange, nonswelling sharp upper and lower contacts.

33. Shale, similar to unit $\mathbf{3 5}$

32. Bentonite similar to unit

31. Shale, similar to unit 35

30. Bentonite, similar to unit $\mathbf{3 4}$

29. Shale, similar to unit 35

28. Bentonite, similar to unit 34

27. Shale, similar to unit 35

25. Shale, similar to unit 35

24. Bentonite, similar to unit 34

23. Shale, similar to unit 35

22. Bentonite, similar to unit 34
Pembina River section-Continued

Pierre Shale (part)-Continued

Pembina Member (part) -Continued Feet

21. Shale, similar to unit 35

20. Bentonite, similar to unit 34

19. Shale, similar to unit 35

18. Bentonite, similar to unit 34_- .25

17. Shale, similar to unit 35.-. 05

16. Bentonite, similar to unit 34

15. Shale, similar to unit 35

14. Bentonite, similar to unit 34. 05

13. Shale, similar to unit 35

12. Bentonite, similar to unit 34

11. Shale, similar to unit 35

10. Bentonite, similar to unit 34

9. Shale, similar to unit 35

8. Bentonite, similar to unit 34

7. Shale, similar to unit 35

6. Bentonite, similar to unit 34

5. Shale, similar to unit 35

4. Bentonite, similar to unit 34

3. Shale, similar to unit 35

2. Limonite and gypsum, rusty-brown, hard_-_.-- 1.40

Total Pierre Shale measured (rounded)

Niobrara Formation (uppermost bed) :

1. Marlstone, yellowish-orange

$2+$

\section{LITERATURE CITED}

Babcock, E. J., and Clapp, C. H., 1906, Economic geology of North Dakota clays : North Dakota Geol. Survey 4th Bienn. Rept., p. 95-189, pls. 6-13.

Bannatyne, B. B., 1963, Cretaceous bentonite deposits of Manitoba: Manitoba Dept. Mines and Nat. Resources, Mines Br. Pub. 62-5, 44 p.

Barry, J. G., and Melsted, V. J., 1908, The geology of northeastern North Dakota with special reference to cement materials: North Dakota Geol. Survey 5th Bienn. Rept., p. 115-211, pls. 20-29.

Connolly, J. P., and O'Harra, C. C., 1929, The mineral wealth of the Black Hills: South Dakota School Mines Bull. 16, $418 \mathrm{p}$.

Crandell, D. R., 1950, Revision of the Pierre shale of central South Dakota: Am. Assoc. Petroleum Geologists Bull., v. 34, no. 12, p. 2337-2346.

_ 1952, Origin of Crow Creek member of Pierre shale in central South Dakota: Am. Assoc. Petroleum Geologists Bull., v. 36, no. 9, p. 1754-1765.

Davies, J. F., Bannatyne, B. B., Barry, G. S., and McCabe, H. R., 1962, Geology and mineral resources of Manitoba: Manitoba Dept. Mines and Nat. Resources, Mines Br., 190 p., 20 pls.

Dawson, A. C., 1942, Manganese occurrences in Manitoba : Manitoba Dept. Mines and Nat. Resources, Mines Br. Prelim. Geol. Rept. 42-1, 23 p.

Dawson, G. M., 1881, On the lignite Tertiary formation, from the Souris River to the 108th meridian: Canada Geol. Survey Rept. Prog. 1879-80, p. 12A-49A.

Elias, M. K., 1931, The geology of Wallace County, Kansas: Kansas Geol. Survey Bull. 18, 254 p., 42 pls.

Gallay, Wilfred, 1938, Canadian bentonites: Canadian Jour. Research, v. 16, p. 6-34. 
Gill, J .R., and Cobban, W. A., 1961, Stratigraphy of lower and middle parts of the Pierre Shale, northern Great Plains, in Short papers in the geologic and hydrologic sciences: U.S. Geol. Survey Prof. Paper 424-D, p. D185-D191.

- 1962, Red Bird Silty Member of the Pierre Shale, a new stratigraphic unit, in Short papers in geology, hydrology, and topography: U.S. Geol. Survey Prof. Paper 450-B, p. B21-B24.

Gries, J. P., 1940, A structural survey of northeastern Stanley County, South Dakota: South Dakota Geol. Survey Rept. Inv. 34, 52 p., 5 pls.

1942, Economic possibilities of the Pierre shale: South Dakota Geol. Survey Rept. Inv. 43, 79 p., 1 pl.

Gries, J. P., and Rothrock, E. P., 1941, Manganese deposits of the lower Missouri valley in South Dakota: South Dakota Geol. Survey Rept. Inv. 38, 96 p., 9 pls.

Halstead, E. C., 1959, Ground-water resources of the Brandon map-area, Manitoba : Canada Geol. Survey Mem. 300, 67 p., 2 maps.

Holland, F. D., Jr., 1961, The status of paleontology in North Dakota : North Dakota Acad. Sci. Proc., v. 15, p. 45-63.

Kirk, S. R., 1930, Cretaceous stratigraphy of the Manitoba escarpment: Canada Geol. Survey Summ. Rept., 1929, pt. B, p. 112B-135B.

Klepper, M. R., Weeks, R. A., and Ruppel, E. T., 1957, Geology of the southern Elkhorn Mountains, Jefferson and Broadwater Counties, Montana : U.S. Geol. Survey Prof. Paper 292, 82 p. [1958].

Kline, V. H., 1942, Stratigraphy of North Dakota: Am. Assoc. Petroleum Geologists Bull., v. 26, no. 3, p. 336-379.

Laird, W. M., 1951, Geology of the Pembina Hills : North Dakota Outdoors, v. 13, no. 12, p. 12-13.

- 1957, Guidebook for geologic field trip in the Devils Lake area, North Dakota-geology month in scouting, October 1957: North Dakota Geol. Survey Misc. Ser., no. 3, 11 p., 6 pls.

Leonard, A. G., 1904, Topographic features and geological formations of North Dakota: North Dakota Geol. Survey 3d Bienn. Rept., p. 127-177, pls. 25-30.

1906, Stratigraphy of North Dakota clays : North Dakota Geol. Survey 4th Bienn. Rept., p. 63-94, pls. 2-5.

1919, The geology of North Dakota: Jour. Geology, v. 27, no. 1, p. 1-27.

MacLean, A., 1916, Pembina Mountain, southern Manitoba : Canada Geol. Survey Summ. Rept., 1915, p. 131-133.

Meek, F. B., 1860, Remarks on the Cretaceous fossils collected by Professor Henry Y. Hind * * * with descriptions of some new species, Chap. 19 in Hind, H. Y., Reports of progress, together with a preliminary and general report, on the Assinniboine and Saskatchewan exploring expedition: London, George Edward Eyre and William Spottiswoode, p. 195198, pls. 1-2.

Owen, D. D., 1852, Report of a geological survey of Wisconsin, Iowa, and Minnesota; and incidentally of a portion of Nebraska Territory: Philadelphia, Lippincott, Grambo and Co., $638 \mathrm{p}$.

Rothrock, E. P., 1947, Geology of the Missouri Valley and vicinity near Mobridge [S. Dak.] : South Dakota Geol. Survey Rept. Inv. $58,29 \mathrm{p}$.

Schmidt, R. G., 1963, Preliminary geologic map and sections of the Hogan 4 Southeast quadrangle, Lewis and Clark County, Montana: U.S. Geol. Survey Misc. Geol. Inv. Map I-379.

Searight, W. V., 1937, Lithologic stratigraphy of the Pierre formation of the Missouri Valley in South Dakota: South Dakota Geol. Survey Rept. Inv. 27, 63 p., 8 pls.

- 1938, The microfauna of the Sully member of the Pierre: Iowa Acad. Sci. Proc., v. 45, p. 135-137.

Spivey, R. S., 1940, Bentonite in southwestern South Dakota: South Dakota Geol. Survey Rept. Inv. 36, 56 p., 7 pls.

Tourtelot, H. A., 1962, Preliminary investigation of the geologic setting and chemical composition of the Pierre shale, Great Plains region: U.S. Geol. Survey Prof. Paper 390, 74 p., 4 pls.

Tourtelot, H. A., Schultz, L. G., and Gill, J. R., 1960, Stratigraphic variations in mineralogy and chemical composition of the Pierre Shale in South Dakota and adjacent parts of North Dakota, Nebraska, Wyoming, and Montana in Short papers in the geological sciences: U.S. Geol. Survey Prof. Paper 400-B, p. B447-B452.

Tovell, W. M., 1948, Geology of the Pembina Valley-Deadhorse Creek area, Winnipeg Division, Manitoba: Manitoba Dept. Mines and Nat. Resources, Mines Br. Prelim. Rept. 47-7, 7 p.

Tyrrell, J. B., 1890, The Cretaceous of Manitoba : Am. Jour. Sci., 3d ser., v. 40, p. 227-232.

Upham, Warren, 1895, The glacial Lake Agassiz : U.S. Geol. Survey Mon. 25, 658 p., 38 pls. [1896].

Wickenden, R. T. D., 1945, Mesozoic stratigraphy of the eastern plains, Manitoba and Saskatchewan: Canada Geol. Survey Mem. 239, 87 p., 5 pls., 3 maps.

Willard, D. E., 1909, Description of the Jamestown-Tower district, North Dakota: U.S. Geol. Survey Geol. Atlas, Folio $168,10 \mathrm{p}$. 

